\title{
A comparative case study of prescribing and non-prescribing physiotherapists and podiatrists
}

\author{
Nicola Carey ${ }^{1 *}$ (D) Judith Edwards ${ }^{1}$, Simon Otter ${ }^{2}$, Heather Gage ${ }^{3}$, Peter Williams ${ }^{4}$, Molly Courtenay ${ }^{5}$, \\ Ann Moore ${ }^{2}$ and Karen Stenner ${ }^{1}$
}

\begin{abstract}
Background: Increasing numbers of nurses, pharmacists and allied health professionals across the world have prescribing rights for medicines: over 90,000 of the eligible United Kingdom workforce are qualified as non-doctor prescribers. In order to inform future developments, it is important to understand the benefits and impact of prescribing by allied health professionals including physiotherapists and podiatrists.

Aim: to compare outcomes of physiotherapist and podiatrist Independent Prescriber (PP- IP) patients with those of physiotherapist and podiatrist non-prescribers (PP-NPs). Outcome measures included patient satisfaction, ease of access to services, quality of life and cost implications.

Design: a mixed method comparative case study.

Methods: Using mixed methods of data collection, outcomes were compared between 7 sites where care was provided from a PP-IP (3 podiatrist and 4 physiotherapist IPs) and 7 sites from a PP-NP ( 3 podiatrist and 4 physiotherapist NPs). Patients were followed up for 2 months (2015-2016).

Results: 489 patients were recruited: $n=243$ IP sites, and $n=246$ NP sites. Independent prescribing was found to be highly acceptable, and equivalent in terms of quality of life $(p>0.05)$ and patient satisfaction $(p \leq 0.05)$ compared to care provided by NPs. PP-IP care delivery was found to be more resource intensive than PP-NP, with longer consultation duration for IPs (around 6.5 mins), and a higher proportion of physiotherapy patients discussed with medical colleagues (around $9.5 \mathrm{~min}$ ).

Conclusion: This study provides new knowledge that PP-IPs provide high levels of care. PP-IP care delivery was found to be more resource intensive. Further research is required to explore cost effectiveness. A more focussed exploration within each profession using targeted outcome measures would enable a more robust comparison, inform future developments around the world and help ensure non-doctor prescribing is recognised as an effective way to alleviate shortfalls in the global workforce.
\end{abstract}

Keywords: Physiotherapy, Podiatry, Independent prescribing, Comparative case study

\footnotetext{
* Correspondence: n.carey@surrey.ac.uk

${ }^{1}$ School of Health Sciences, University of Surrey, Kate Granger Building, Guildford GU2 7YH, UK

Full list of author information is available at the end of the article
}

(c) The Author(s). 2020 Open Access This article is licensed under a Creative Commons Attribution 4.0 International License, which permits use, sharing, adaptation, distribution and reproduction in any medium or format, as long as you give appropriate credit to the original author(s) and the source, provide a link to the Creative Commons licence, and indicate if changes were made. The images or other third party material in this article are included in the article's Creative Commons licence, unless indicated otherwise in a credit line to the material. If material is not included in the article's Creative Commons licence and your intended use is not permitted by statutory regulation or exceeds the permitted use, you will need to obtain permission directly from the copyright holder. To view a copy of this licence, visit http://creativecommons.org/licenses/by/4.0/ The Creative Commons Public Domain Dedication waiver (http://creativecommons.org/publicdomain/zero/1.0/) applies to the data made available in this article, unless otherwise stated in a credit line to the data. 


\section{Background}

As life expectancy increases, and the world's population continues to grow [1-3], many countries are shifting the focus of their health system from acute to chronic diseases, alongside managing increasing service demands [4]. Recent data from the United Kingdom (UK), United States (US) and across Europe confirms 25\% of adults take three or more medicines each day $[2,5]$ and that by 2020 the world's population will receive 4.5 trillion doses of medicine each year [5-7].

There is however, a worldwide deficit of 18 million health workers [8], with a predicted 350,000 shortfall in the UK, and a third of the current workforce due to retire by 2030 [9]. Inadequacies with traditional doctor/physician-led care systems mean that in order to maintain patient access to prescription medicines, new approaches are imperative [9, 10]. Allied Health Professionals, (health professionals who are not medical doctors, physicians, nurses. Pharmacists or dentists), e.g. therapeutic radiographers, paramedics, podiatrists and physiotherapists (AHP) have in particular been identified as having an integral role to the required transformational change [11].

Extending prescribing rights to nurses, pharmacists and allied health professions $[12,13]$ has been the focus of a UK policy drive to improve services and access to medicines by making better use of existing skills and support service innovation $[11,14-16]$. Of the 907,000 UK healthcare professionals entitled to undertake prescribing training [17], over 90,000 of the eligible workforce are now qualified as prescribers [17], placing the UK as the forerunner in the development of non-doctor prescribing, also known as non-medical prescribing, worldwide.

In the UK, Independent Prescribing (IP) and Supplementary Prescribing (SP) are two different forms of nondoctor prescribing. Training typically involves 27 classroom days, a mandatory aspect of supervised practice, and robust academic and practice assessment [18-20], a dual qualification in IP and SP being awarded to registered nurses, pharmacists, radiographers and paramedics, podiatrists and physiotherapists. Supplementary prescribing rights were extended to some allied health professions in 2005, with further changes to legislation in 2013 permitting physiotherapists and podiatrists to prescribe medicines independently [21-23]. Apart from some restrictions around independent prescribing of controlled drugs and in line with other allied health professions, physiotherapists and podiatrists, normally with 3 years relevant post qualification experience, are able to independently prescribe any medicine within their area of competence without the need for a doctor. By contrast supplementary prescribing defined as dependent prescribing, is based on an initial diagnosis by a doctor and an agreed clinical management plan detailing medicines that can be prescribed [24].
Although several other countries, including Australia, Ireland, and Netherlands, have seen similar developments in non-medical prescribing, approaches to training, accreditation and models of prescribing practice are varied [25-28]. Physiotherapists have for example, authorisation to provide advice about and/or to administer or supply medicines in some states in Australia, New Zealand and Canada, but only those in the US military can prescribe $[29,30]$. Podiatrists have similar authority in Australia and some European countries but are only entitled to prescribe in some Canadian provinces [29, 31].

When used by nurses and pharmacist, independent and supplementary prescribing are reported as acceptable and beneficial to patients, with some evidence of enhanced clinical outcomes compared to doctors [26, 32-34]. A recent systematic review reported that non-medical prescribing has no adverse impact upon patient outcomes, patient satisfaction or resource utilisation [35]. Reviews on the impact of extended physiotherapist roles reveal research hampered by small numbers, role variation and poor role definition [36, 37], literature dominated by service descriptions and audit with positive reporting bias $[29,36,37]$, and a lack of evidence regarding podiatric practice [29]. Whilst physiotherapist and podiatrist supplementary prescribing helps streamline service delivery $[38,39]$, independent prescribing is expected to bring additional benefits in line with nurse and pharmacist prescribing $[40,41]$. Exploration of clinical and cost effectiveness in this area is limited with inconclusive findings [42-47]. As most evidence relates to nurses and pharmacists, it is important to evaluate the impact of prescribing by allied health professionals in order to inform commissioning and implementation of non-medical prescribing services where they are beneficial.

Seven years after the introduction of current legislation enabling physiotherapists and podiatrists to independently prescribe medicines, there were (as of October 2020) 1295 physiotherapists and 442 podiatrists with an annotation as independent prescriber, with a further 108 physiotherapists and 67 podiatrists registered as supplementary prescribers [48]. There is a lack of evidence of reporting on physiotherapist and podiatrist independent prescribing practice, or the medicines they prescribe and no studies available which quantify the impact of podiatrist and physiotherapist independent prescribing on patient satisfaction, access to services, quality of life or report cost-implications of care delivery [29]. This is important given the increasing emphasis in the UK and around the world on extending prescribing rights to nurses, pharmacists and allied health professionals as a key strategy in addressing workforce deficits and ensuring patients have ongoing access to medicines [8-10, 49]. 


\section{Methods}

Aim

Was to compare the outcomes of patients managed by physiotherapist and podiatrist independent prescribers (PP- IP) with those under the care of physiotherapist and podiatrist non-prescribers (PP-NPs). Outcome measures included patient satisfaction, ease of access to services, quality of life and costs.

\section{Study design}

This study was commissioned to undertake concurrent evaluation of physiotherapist and podiatrist independent prescribing reflecting the 2013 regulatory changes introduced to both professions. A comparative case study methodology used in situations when no single outcome measure is available was adopted [50, 51]. Outcomes were compared between 7 sites where patients received care from a PP-IP (3 podiatrist and 4 physiotherapist IPs) and 7 sites where care was provided by a PP-NP without a prescribing qualification (3 podiatrist and 4 physiotherapist non-prescribers) [52]. Mixed methods (including interviews, structured observation of consultations, patient questionnaires) were used to collect data at each of the 14 sites during a 5 -day period of observation of practice. Details of data collection tools, methods and piloting are shown in Table 1.

The original intention was to collect data on patient follow-up treatments and re-consultations by audit of clinic records at 2 months. It was evident that this was limited and inconsistent during data collection at the first four sites. The protocol was therefore amended to include a second patient questionnaire for self-report usage of health services in the 2 months after the index consultation. Data collection took place simultaneously January 2015-March 2016.

\section{Sample size}

Anticipating patient satisfaction and ease of access to services being best expressed as positive or negative responses, in order to detect an absolute underlying difference of $40 \%$ between PP-IP and NP-PP, with size $=5 \%$ and power $=$ $80 \%$, a minimum of 24 subjects were needed in each PP-IP and NP-PP site. Allowing for a dropout rate of $20 \%$, to enable a statistically sound comparison to be made between any specific pair of PP-IP and NP-PP sites, a target recruitment of 30 patients per site (total $n=420$ ), collected over a maximum of 5 working days, was set.

Initial sample estimates, based on information provided by physiotherapists and podiatrists in clinical practice, indicated that full-time PP-IPs/NP-PPs have up to 60 consultations, lasting approximately 20-40 min each, per week, generating data on potentially 840 patient care episodes across 14 sites, indicated that, even allowing for repeat patient visits and inclusion criteria failures, such a recruitment was feasible.

\section{Case sites}

Sites with physiotherapist and podiatrist independent prescribers were purposively selected from an earlier study phase [52] to include diversity with respect to care setting, geographical location and patient demographics across England.

\section{Recruitment \\ Podiatrists and physiotherapists}

Initial email/ telephone contact was made with physiotherapist and podiatrist independent prescribers who had completed an earlier survey whilst undertaking independent prescribing training $(n=70)$ and indicated willingness to participate in further research [52]. Those who expressed an interest were provided with a participant information sheets and supplementary information on case site involvement and requested to ensure organisational and local Research and Development support.

Non-prescribing physiotherapist and podiatrist sites, matched on professional role, care setting, geographical location and using NHS Agenda for Change (Afc) national pay scale banding [69], were either nominated by PP-IPs, identified through personal contacts of the project advisory group or enquiries from individual Research and Development departments via the National Institute of Health Research (NIHR) portfolio. These matched NPPPs were, with consent, contacted by a member of the research team and recruited following the same process as for PP-IPs. Written informed consent was taken from PPIPs and NP-PPs on the first day of each case site visit by JE, who assured on-going consent with each PP-IP or NPPP at the beginning of each contact day.

\section{Patients}

At each case site a consecutive sample of patients who had scheduled appointments with physiotherapist and podiatrist independent prescribers/ non-prescribers providing adult services during a 5-day (up to $37 \mathrm{~h}$ ) site visit by the study researcher (JE) were recruited in NHS sites by trained research nurses, and private sites by a second study researcher (EK) between March 2015 and February 2016. Informed written consent was obtained from those who were willing to participate.

A screening log of all patients approached for participation in the study $(n=563)$ was recorded; both those recruited to the study $(n=488,86.7 \%)$ and those declining participation $(n=75,13.3 \%)$, including hospital/unit medical record numbers, gender and the date of consent, by the local research nurse/ study researcher. Following the observed consultation (see Table 1) those who agreed to participate completed and posted Patient 
Table 1 Summary of data collection arrangements and instruments

\begin{tabular}{|c|c|c|c|c|}
\hline $\begin{array}{l}\text { Category of } \\
\text { data }\end{array}$ & $\begin{array}{l}\text { Method of } \\
\text { data } \\
\text { collection }\end{array}$ & $\begin{array}{l}\text { Timing of } \\
\text { collection }\end{array}$ & Items and instruments & Piloting \\
\hline $\begin{array}{l}\text { 1) } \\
\text { Characteristics } \\
\text { of PPs \& sites }\end{array}$ & $\begin{array}{l}\text { i) Structured } \\
\text { interview and } \\
\text { site visit }\end{array}$ & $\begin{array}{l}\text { Prior to observation } \\
\text { period }\end{array}$ & $\begin{array}{l}\text { Setting and geographic location } \\
\text { PPs profile: Age, gender, highest educational } \\
\text { qualification, salary/band, full/part time } \\
\text { status, job title/role; } \\
\text { Service Information: service description \& } \\
\text { patient profile, single or multi-professional } \\
\text { team, other NMPs in team }\end{array}$ & $\begin{array}{l}\text { Interview schedules were reviewed by } \\
\text { research team and project advisory group. } \\
\text { Main interviewer (JE) was buddied by } \\
\text { experienced team member (KS) for first two } \\
\text { interviews in order to provide guidance and } \\
\text { clarify and address any issues with the } \\
\text { interview schedule. } \\
\text { Following this, minor revisions were made } \\
\text { to improve the flow of questions. }\end{array}$ \\
\hline
\end{tabular}

$\begin{array}{llll}\text { 2) Patient } & \text { i) Patient } & \text { Post consultation } & \text { Socio-demographics: age, gender, living } \\ \text { characteristics } & \text { questionnaire } 1 & \text { and } 2 \text { months } & \text { arrangements; accommodation, } \\ & \& 2 & \text { following } & \text { employment; education; ethnicity }\end{array}$

3) Patient reported outcomes

4) PPs activities i) Patient Post consultation questionnaire 1 Post- consultation ii) Patient and 2 months questionnaire1 following and 2 consultation (excluding 1st four sites) i) Observation Real-time service

diary completed by researcher ii) Prescriptions delivery up to 5 working days (37 h) Real-time service delivery up to 5 working days (37 h)
Patient satisfaction: with consultation, advice and medicines information comprised subscales from several validated tools (total 24 items):

i) Consultation Satisfaction Questionnaire i.e. 'professional care', 'perceived time' and 'overall satisfaction' and ii) Medical Interview Satisfaction Survey (MISS) $[53,54]$ 'compliance intent' (10 items) \& for patients who received medicines information or advice questions from PP iii) Satisfaction with Information about Medicines (SIMS) Scale [55] e.g. dose schedule, how medicine works, side-effects, and medicines adherence) [54-57] (14 items).

Service Satisfaction: was measured by 7 items on ease of access to services from the outpatients' opinion of quality of hospital departments questionnaire [58]-7 items. Attitudes towards PP-IP $[56,59]-4$ items. 6 point Likert scales (strongly disagree to strongly agree) used for all items

Quality of life validated EQ-5D-5L [60] comprising 5 dimensions, from independent dependent, with 5 weighted levels affording a single index value score. (i.e. mobility, selfcare, usual activities, pain/discomfort and anxiety/depression)

Using a Microsoft Access@ custom built electronic diary based on previous validated tools [61-63], a researcher recorded details of the model of service provision and MMA (including outcome and prescribing actions) during each observed consultation. Model of service provision: Consultation duration (in minutes); type of consultation (face to face, telephone, email) and appointment (initial, follow-up, emergency), service \& referral source (e.g. NHS in/outpatient, community, GP, social enterprise, private). Other work activities in relation to care included referrals made (to whom and how), discussion with colleagues, time spent in discussions with colleagues and review arrangements.

MMA i) outcome: whether a new medication was required; decisions to alter, stop, or
Q1: Patients ( $n=5)$ completed and commented on ease of comprehension, length and time. Based on comments no refinements were made.

Q2: piloted concurrently at first site (casesite 3). After first 10 completed, ease of use, consistency and question completion rate were discussed with no amendments or changes required.

Formal piloting was undertaken in January 2015 in a secondary care based rheumatology outpatient clinic (not designated as a site). Five completed questionnaires were returned with comments indicating that content, layout and design was comprehensive and completion time was of acceptable length, ranging from 9 to $15 \mathrm{~min}$.

Questionnaire 2 was implemented following data collection completion at the first four

sites, and was piloted concurrently at the first site visited (site 3 ) after its approval. After the first 10 completed questionnaires, ease of use, consistency and question completion rate were discussed at team meetings; no amendments or changes were required.

Details of 8 observed consultations were recorded and downloaded into Microsoft Excel@. Data were found to be comprehensive, and the template layout/ design revised following team discussion data.

There was no piloting of the assessment tool as it had been used in previous studies $[41,68]$. 
Table 1 Summary of data collection arrangements and instruments (Continued)

\begin{tabular}{lllll}
\hline $\begin{array}{l}\text { Category of } \\
\text { data }\end{array}$ & $\begin{array}{l}\text { Method of } \\
\text { data } \\
\text { collection }\end{array}$ & $\begin{array}{l}\text { Timing of } \\
\text { collection }\end{array}$ & Items and instruments & Piloting \\
\hline
\end{tabular}

\begin{tabular}{|c|c|c|c|}
\hline \multirow{4}{*}{$\begin{array}{l}\text { 5) Resource } \\
\text { implications } \\
\text { and costs }\end{array}$} & $\begin{array}{l}\text { i) Interviews } \\
\text { with PP }\end{array}$ & $\begin{array}{l}\text { Prior to baseline } \\
\text { data collection }\end{array}$ & $\begin{array}{l}\text { Grade/ banding of each of the PPs in the } \\
\text { study. }\end{array}$ \\
\hline & $\begin{array}{l}\text { ii) Observation } \\
\text { diary } \\
\text { completed by } \\
\text { researcher }\end{array}$ & $\begin{array}{l}\text { Real-time service } \\
\text { delivery up to } 5 \\
\text { working days ( } 37 \mathrm{~h} \text { ) }\end{array}$ & $\begin{array}{l}\text { Six items related to consultations with } \\
\text { individual patients were also examined for } \\
\text { differences between PP-IPs and NP-PP-NPs } \\
\text {-number and duration of consultations } \\
\text { - frequency \& duration of discussions with } \\
\text { colleague or other professional regarding } \\
\text { patient's medication } \\
\text {-frequency of new medications } \\
\text {-frequency of referrals and follow-up } \\
\text { consultations }\end{array}$ \\
\hline & $\begin{array}{l}\text { iv) Patient } \\
\text { record audit }\end{array}$ & $\begin{array}{l}\text { Clinical records } 2 \\
\text { months following } \\
\text { consultation. } \\
\text { A maximum of } 15 \\
\text { patients per site } \\
\text { were selected. }\end{array}$ & $\begin{array}{l}\text { Requested investigations, tests (e.g. BP, } \\
\text { bloods, x-ray, MRI scan, CT, urine, sputum } \\
\text { etc.) and referrals and services used relevant } \\
\text { to the presenting complaint (i.e. case site PP, } \\
\text { consultant specialist, clinical nurse specialist, } \\
\text { GP, GP based nurse/ nurse practitioner, com- } \\
\text { munity nurse pharmacists, social services, } \\
\text { other healthcare professionals) other hos- } \\
\text { pital outpatients, hospital admissions, and } \\
\text { number of in-patient days, A\&E visits etc. }\end{array}$ \\
\hline & $\begin{array}{l}\text { iii) Patient } \\
\text { questionnaire } 2\end{array}$ & $\begin{array}{l}2 \text { months following } \\
\text { consultation } \\
\text { (excluding first } 4 \\
\text { sites) }\end{array}$ & $\begin{array}{l}\text { Self- report use of health services for PP } \\
\text { related issues in the previous } 2 \text { months } \\
\text { including: tests received, referrals, follow-up } \\
\text { consultations, un-planned consultation; visits } \\
\text { or contact with GPs, clinical nurse specialist, } \\
\text { pharmacists, social services, other healthcare } \\
\text { professionals, hospital outpatient clinics, A\&E } \\
\text { visits, hospital admissions, and number of in- } \\
\text { patient days }\end{array}$ \\
\hline
\end{tabular}

(as reported above)

(as reported above)

Audit tool: was piloted on 8 sets of medical records. Concerns were raised about quality of available data and that retrospective data collection could present difficulties with potential incomplete data. Following data collection at first four sites an amendment to the study protocol, as previously described was made.
Questionnaire 1 into a box in the clinic area or returned using pre-paid envelopes.

\section{Data collection}

An initial telephone interview, informed by previous work in the area [70] was conducted with the physiotherapist and podiatrist from each site using semi-structured questions to gather information on site characteristics, and professional role. Details of the data collection and instruments, informed by the study patient and public involvement and advisory groups, are presented in Table 1. All data collection instruments were piloted in a non-study 
physiotherapist independent prescriber NHS outpatient clinic in January 2015, with only minor corrections to wording required (see Table 1).

\section{Outcome measures}

Baseline questionnaire 1 Informed by previous work [70] and several validated tools [53-57, 71, 72] a patient questionnaire was constructed to ensure that the generic questionnaire developed to evaluate prescribing by nurses and midwives in the Republic of Ireland [56] was appropriately adapted.

Section 1 recorded patient satisfaction with services received at the time of consultation using 10 medical interview satisfaction questions $[55,56]$ and 'ease of access' to services using 7 additional questions [58].

Section 2 comprised 4 statements measuring patients' attitudes to physiotherapist and podiatrist independent prescribers $(65,68)$ and 14 statements about the advice/ information they may have received from physiotherapist and podiatrist independent prescribers/ non-prescribers during the consultation including side effects, action of use and dose schedule and medicines adherence [54-57].

Section 3 employed the validated EQ-5D-5L quality of life profile measure of five dimensions (mobility, selfcare, usual activities, pain, anxiety/ depression) rated on five levels (no problem to severe problem/ unable questionnaire [60]. Although the standardized extended EQ5D incorporates a vertical $20 \mathrm{~cm}$ visual analogue scale (VAS) rating scale, patient and public involvement group members consistently reported difficulty indicating numerical values for how they felt at any one time point. It was therefore decided to exclude this from the questionnaire.

Section 4 comprised 7 items related to general demographics in order to describe respondent characteristics including age, living arrangements, employment, ethnic group and educational attainment.

Follow up questionnaire 2 Comprised of 5 questions relating to health resource use in addition to a second completion of the EQ-5D-5L asked over telephone. Patients were asked if they had, in the 2-month period following consultation received medicines prescribed/ recommended by the physiotherapist and podiatrist independent prescribers/ non-prescribers, undergone diagnostic tests (e.g. radiology, blood tests), returned to the physiotherapist and podiatrist independent prescribers/ non-prescribers for follow-up treatment, been referred to other services/professionals, or received unplanned treatment for the same condition following the initial consultation (list of 10 potential services) (see Table 1).

\section{Data analysis}

Quantitative data were entered on to SPSS $\odot$ Version 22. Descriptive statistics were used to summarise the data and reported where open text data (specifically in relation to medication details and requested tests from the observation diary) had been converted to numeric data. Patient satisfaction and ease of access to services were measured on a 5-point Likert scale or as Yes/No responses. The Likert scale responses were easily reducible to positive or negative responses.

When assessing change in EQ-5D-5L descriptive health score from Patient Questionnaire 1 to Questionnaire 2, a paired t-test was used.

When comparing 2 subgroups for normally distributed outcomes (notably change scores from Questionnaire 1 to Questionnaire 2, such as for overall EQ-5D-5L score), an unpaired t-test was utilised.

When comparing 2 subgroups (in particular prescribing and non-prescribing) for an ordinal outcome, a Mann-Whitney U test was utilised. When comparing 2 subgroups (notably Podiatry and Physiotherapy or prescribing and non-prescribing) for a categorical outcome, the Chi-Squared test was used, reverting to a Fisher's Exact test in $2 \times 2$ cross tabulations if 1 or more expected cell count was found to be $<5$.

\section{Economic analysis}

Seven resource implications of independent prescribers compared to non-prescribers were originally considered: rates of prescribing tests ordered; referrals to other health professionals; frequency of follow up; consultation duration; time spent discussing the patient with other colleagues; unplanned consultations for the same condition within two months of the index consultation. Data were gathered through the observation diary, except for tests (from the retrospective audit) and unplanned consultations (from the patient follow up questionnaire). Group level comparisons of independent prescribers compared to non-prescribers for physiotherapists and podiatrists were undertaken separately for each of the seven variables.

The cost implications (British pounds 2015) of differences in consultation length and colleague's time spent in discussion were examined by applying nationally valid unit costs [73]. A comprehensive micro level costing analysis could not be conducted because data on tests and unplanned consultations were only gathered for a sample of patients and insufficient details were available on medications, referrals and planned follow up to enable costs to be reliably ascribed. Costs that could be estimated were considered in relation to outcomes (satisfaction with consultation, satisfaction with advice, changes in health-related quality of life (EQ-5D-5L) 
between baseline and follow up) in a simple cost consequences framework.

\section{Results \\ Characteristics of participants}

\section{i) PPs and case sites}

Seven matched pairs of sites, ( 3 podiatry and 4 physiotherapy) were recruited. Sites were based across 8 Academic Health Science Networks in England (https:// www.ahsnnetwork.com/), provided adult services, a mixed range of settings, including private practice $(n=$ $2)$, primary care $(n=6)$, secondary care $(n=6)$, social enterprise $(n=2)$ and were well matched by professional role, care setting and agenda for change banding (see Table 2). All physiotherapist and podiatrist independent prescribers had been qualified for at least 12 months prior to data collection. A total of 488 patients were recruited: 243 across the PP-IP sites with 245 across the NP-PP sites.

Nearly all consultations $(n=474)$, both independent prescribers and to non-prescribers, were face to face ( $n=473,99.8 \%$ ), duration $2-203 \mathrm{~min}$. There was considerable variation in the location of services: $39.2 \%(n=$ 186) of consultations were provided in NHS hospital outpatients, $25.1 \%(n=119)$ NHS community clinics, 20.3\% $(n=96)$ private practice, 9.7\% $(n=46)$ general practice, $4.4 \%(n=21)$ social enterprise and $1.3 \%(n=6)$ community service. Of the observed consultations 112 (23.6\%) included a medicine related activity, where either a new medication, repeat medication (same dosage) or repeat medication with a change to dosage was required, with patients requiring a total of 124 items of medicine (see Table 3).

Almost all medicines related activity within physiotherapy sites, both independent prescribers and nonprescribers, was related to pain and movement control, either via pain medication or through injection therapy. There was one incident where a patient was advised to alter contraception use following surgery by an independent prescriber. A wider range of medication types were used by podiatrists, both independent prescribers and to non-prescribers, the most common being antimicrobial/anti-fungal topical creams, antibiotics and pain medication. Patients requiring medicines recommended by non-prescribers, both podiatrists and physiotherapists, were subsequently referred to a medical doctor in the usual way.

\section{ii) Patients}

Demographic data (see Table 4) were collected from 315/ 468 (67.3\%) patients who consented to and returned patient questionnaire 1: 49.5\% $(n=156)$ were from prescribing and $50.5 \% \quad(n=159)$ from nonprescribing sites. A lack of benchmark data with which to compare the patient data means it is not possible to confirm how representative our sample is with respect to the larger population. However, the samples, from the prescribing and non-prescribing group in this study were similar in terms of age, employment status, level of formal education, and ethnic group $(p>0.05)$.

\section{Follow up questionnaire 2}

A response rate of $73.7 \%(197 / 267)$ was obtained for questionnaire 2 . This sample excluded the 175 participants from the first 4 sites (Sites 1, 2, 4, 7) (see Table 2). Of the remaining 313 participants, 285 consented to follow-up, however contact details were incorrect or missing for 18 participants, leaving 267 eligible to participate.

\section{iii) Patient outcomes}

a) Satisfaction and access to services

The majority of patients $(75.9 \%, n=239)$ agreed that physiotherapists and podiatrists should be able to prescribe medicines for patients, however 23.2\% $(n=73)$ would prefer a doctor to prescribe. Levels of satisfaction for the sample as a total were high, with over $60 \%$ positive agreement on all items other than ability to contact the service in an emergency $(n=144,44.4 \%)$. Satisfaction with 17 specified aspects of the consultation and services provided by physiotherapists and podiatrists indicated a significantly higher level of satisfaction among the patients of physiotherapist and podiatrist independent prescribers than those of non-prescribers in 8 instances (Table 5).

With respect to service access, patients of podiatrist independent prescribers were more satisfied with 'the ease of making an appointment' and 'the ability to contact the service by phone or in times of emergency' (see Table 5) than patients of the non-prescribing podiatrists, with no notable difference evident in patients attending physiotherapist prescribers compared to patients of nonprescribing physiotherapists.

There was no effect on the remaining four items reporting on ease of access on the acceptability of: i) waiting time to obtain an appointment; ii) obtaining an appointment on a convenient day or hour; iii) waiting time or iv) seeing the physiotherapist or podiatrist at the appointed time between patients attending a physiotherapist or podiatrist independent prescriber when compared to those attending a non-prescribing physiotherapist or podiatrist.

Patients of a physiotherapist or podiatrist independent prescribers were more likely to receive medicines information or advice during the consultation (58 out of 146 


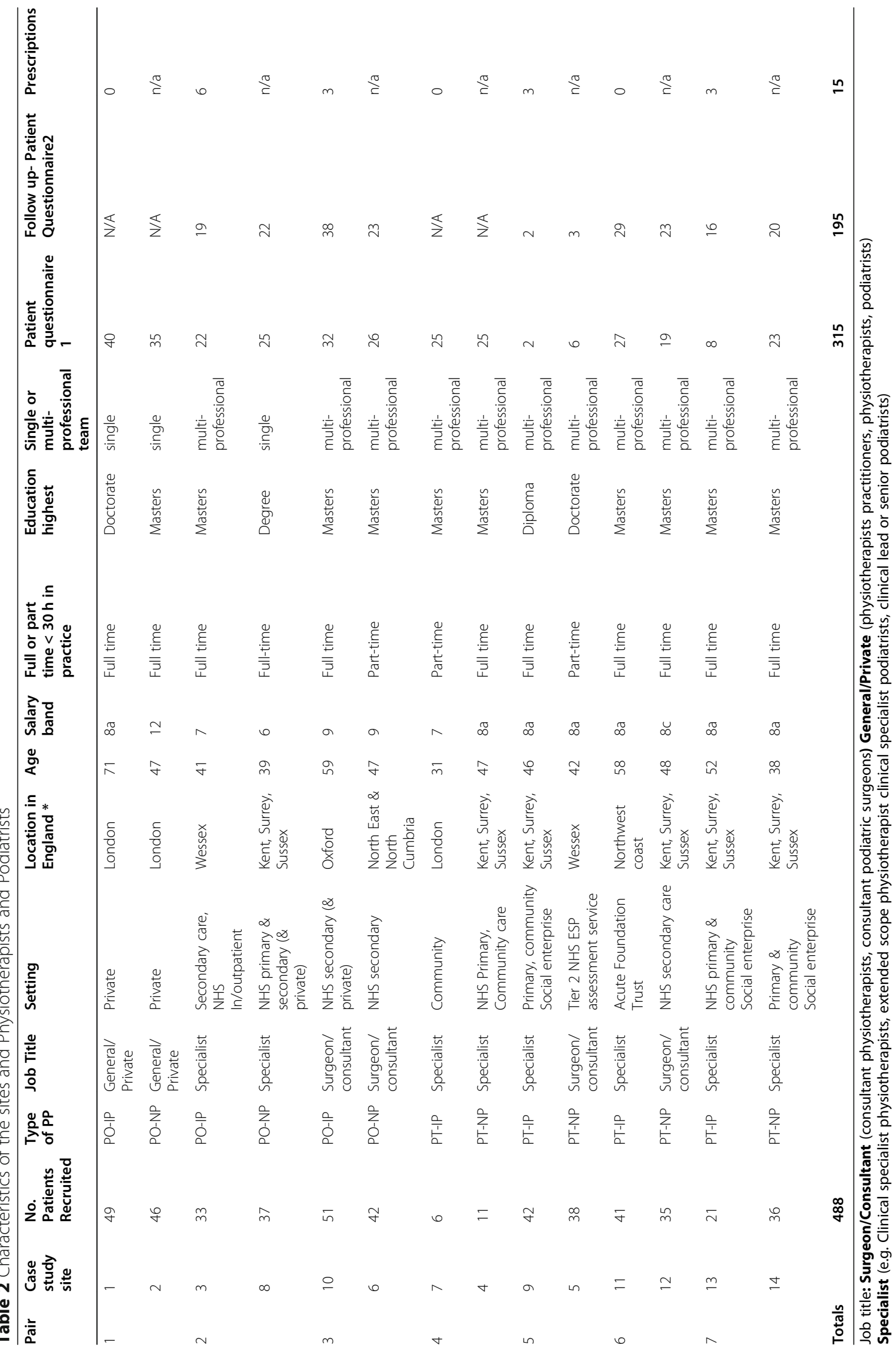


Table 3 Consultations with medicines related activity

\begin{tabular}{|c|c|c|c|c|c|c|c|c|}
\hline $\begin{array}{l}\text { Number of observed } \\
\text { consultations }\end{array}$ & $\begin{array}{l}\text { Physiotherapist } \\
\text { IP } \\
n=107\end{array}$ & $\begin{array}{l}\text { Number } \\
\text { of items } \\
n=37\end{array}$ & $\begin{array}{l}\text { Physiotherapist } \\
\text { NP } \\
n=115\end{array}$ & $\begin{array}{l}\text { Number } \\
\text { of items } \\
n=29\end{array}$ & $\begin{array}{l}\text { Podiatrist } \\
\text { IP } \\
n=128\end{array}$ & $\begin{array}{l}\text { Number } \\
\text { of items } \\
n=45\end{array}$ & $\begin{array}{l}\text { Podiatrist } \\
\text { NP } \\
n=124\end{array}$ & $\begin{array}{l}\text { Number } \\
\text { of items } \\
n=13\end{array}$ \\
\hline $\begin{array}{l}\text { Consultations with no medicines } \\
\text { related activity }\end{array}$ & 75 & $\mathrm{n} / \mathrm{a}$ & 87 & $\mathrm{n} / \mathrm{a}$ & 93 & $\mathrm{n} / \mathrm{a}$ & 114 & \\
\hline \multicolumn{9}{|l|}{ Consultations with medicines activity } \\
\hline New medication & 23 & $\begin{array}{l}21 \times 1 \\
2 \times 2 \\
3 \times 1\end{array}$ & 27 & $\begin{array}{l}26 \times 1 \\
1 \times 2\end{array}$ & 31 & $\begin{array}{l}27 \times 1 \\
3 \times 2 \\
1 \times 4\end{array}$ & 10 & $\begin{array}{l}7 \times 1 \\
3 \times 2\end{array}$ \\
\hline Repeat medication (same dosage) & 9 & $9 \times 1$ & 1 & 1 & 2 & $2 \times 2$ & 0 & 0 \\
\hline $\begin{array}{l}\text { Repeat medication (dosage } \\
\text { changed) }\end{array}$ & 0 & 0 & 0 & 0 & 2 & $2 \times 2$ & 0 & 0 \\
\hline $\begin{array}{l}\text { Total number of consultations with } \\
\text { medicines related activity }\end{array}$ & $n=32$ & $\mathrm{n} / \mathrm{a}$ & $n=28$ & $\mathrm{n} / \mathrm{a}$ & $n=35$ & $\mathrm{n} / \mathrm{a}$ & $n=10$ & $\mathrm{n} / \mathrm{a}$ \\
\hline
\end{tabular}

Table 4 Patient characteristics

\begin{tabular}{|c|c|c|c|c|}
\hline & $\begin{array}{l}\text { Physiotherapy } \\
\text { n (\%) }\end{array}$ & $\begin{array}{l}\text { Podiatry } \\
\text { n (\%) }\end{array}$ & $\begin{array}{l}\text { Total } \\
\mathrm{n}=\text { number of responses }\end{array}$ & $\%$ of total sample \\
\hline \multicolumn{5}{|l|}{ Professional group } \\
\hline Which professional consulted & $135(42.86 \%)$ & $180(57.14 \%)$ & 315 & $100 \%$ \\
\hline Gender & & & $n=254$ & \\
\hline Male & $34(30.4 \%)$ & $55(38.7 \%)$ & 89 & $35 \%$ \\
\hline Female & $78(69.6 \%)$ & $87(61.3 \%)$ & 165 & $65 \%$ \\
\hline \multicolumn{5}{|l|}{ Age } \\
\hline \multicolumn{5}{|c|}{ Physiotherapy group: $n=111$, mean 59.7, SD 16.6, (range 17.6-100.98) } \\
\hline \multicolumn{5}{|c|}{ Podiatry group: $n=139$, mean 67.1, SD 16.16, (range 16.17-94.32) } \\
\hline \multicolumn{5}{|l|}{ Total: $n=250$, mean 63.8, SD 16.7} \\
\hline Living arrangements & & & $n=257$ & \\
\hline Live alone & $19(17.4 \%)$ & $32(21.6 \%)$ & 51 & $19.8 \%$ \\
\hline Live with other adult(s) & $90(82.6 \%)$ & $94(63.5)$ & 184 & $71.6 \%$ \\
\hline Care home resident & 0 & $22(14.9 \%)$ & 22 & $8.6 \%$ \\
\hline Type of accommodation & & & $n=276$ & \\
\hline Owner occupied house/flat & $97(82.2 \%)$ & $104(65.8 \%)$ & 201 & $72.8 \%$ \\
\hline Privately rented house/flat & $12(1.02 \%)$ & $12(7.6 \%)$ & 24 & $8.7 \%$ \\
\hline Local authority/housing association/cooperative & $9(7.6 \%)$ & $13(8.2 \%)$ & 22 & $8 \%$ \\
\hline Residential or care home, hospice & 0 & $29(18.4 \%)$ & 29 & $1.05 \%$ \\
\hline Employment group & & & $n=262$ & \\
\hline In paid or voluntary employment & $46(41.1 \%)$ & $40(26.7 \%)$ & 86 & $32.8 \%$ \\
\hline Unemployed/student/at home/sick & $15(13.4 \%)$ & $12(8 \%)$ & 27 & $10.3 \%$ \\
\hline Retired & $51(45.5 \%)$ & $98(65.3 \%)$ & 149 & $56.9 \%$ \\
\hline Educated beyond 18 years & & & $n=274$ & \\
\hline Yes & 32 (27.4\%) & 51 (32.5\%) & 83 & $30.3 \%$ \\
\hline No & 85 (72.6\%) & $106(67.5 \%)$ & 191 & $69.7 \%$ \\
\hline Ethnic group & & & $n=283$ & \\
\hline White & 117 (96.7\%) & 160 (98.8\%) & 277 & $97.9 \%$ \\
\hline Other & $4(3.3 \%)$ & $2(1.2 \%)$ & 6 & $2.1 \%$ \\
\hline
\end{tabular}


Table 5 Patient views and experience of satisfaction with care received from physiotherapist or podiatrist

\begin{tabular}{|c|c|c|c|c|c|c|c|c|c|c|c|c|}
\hline \multirow[t]{3}{*}{$\begin{array}{l}\text { Patient views and experience of } \\
\text { consultation with physiotherapist or } \\
\text { podiatrist } \\
\text { (R) indicates reverse score item }\end{array}$} & \multirow{2}{*}{\multicolumn{4}{|c|}{$\begin{array}{l}\begin{array}{l}\text { Physiotherapist } \\
\text { Independent }\end{array} \begin{array}{l}\text { Physiotherapist } \\
\text { Non-prescriber } \\
\text { Prescriber }(n=\quad(n=73) \\
62)\end{array} \\
\text { Strongly Agree/Agree } \\
\text { (compared with strongly disagree/ } \\
\text { disagree/no opinion) }\end{array}$}} & \multirow{3}{*}{$\begin{array}{l}\text { Mann- } \\
\text { Whitney } \\
\text { U-test }\end{array}$} & \multirow{3}{*}{$\begin{array}{l}\text { Podiatrist } \\
\text { Independent } \\
\text { Prescriber } \\
\text { ( } n=94 \text { ) } \\
\text { Strongly Agree } \\
\text { (compared wit } \\
\text { disagree/no op } \\
\mathbf{n}\end{array}$} & \multirow{2}{*}{\multicolumn{3}{|c|}{$\begin{array}{l}\text { Podiatrist } \\
\text { Non-prescriber } \\
(n=86) \\
\text { /Agree } \\
\text { h strongly disagree/ } \\
\text { inion) }\end{array}$}} & \multirow[b]{3}{*}{$P *$} & \multirow{2}{*}{\multicolumn{2}{|c|}{$\begin{array}{l}\text { Total } \\
n=315 \\
\\
\text { Strongly } \\
\text { Agree/ } \\
\text { Agree }\end{array}$}} \\
\hline & & & & & & & & & & & & \\
\hline & $\mathrm{n}$ & $\begin{array}{l}\% \\
\text { sample }\end{array}$ & $\mathrm{n}$ & $\begin{array}{l}\% \\
\text { sample }\end{array}$ & & & $\begin{array}{l}\% \\
\text { Sample }\end{array}$ & $\mathrm{n}$ & $\begin{array}{l}\% \\
\text { sample }\end{array}$ & & $n$ & $\%$ \\
\hline $\begin{array}{l}\text { 1. Overall I was satisfied with the } \\
\text { consultation from this physiotherapist or } \\
\text { podiatrist }\end{array}$ & 59 & $95.1 \%$ & 67 & $91.2 \%$ & 0.280 & 85 & $90.4 \%$ & 80 & $93.0 \%$ & 0.281 & 291 & $92.4 \%$ \\
\hline $\begin{array}{l}\text { 2.The physiotherapist or podiatrist was very } \\
\text { careful to check everything when carrying } \\
\text { out my care }\end{array}$ & 60 & $96.8 \%$ & 69 & $94.5 \%$ & 0.092 & 82 & $87.2 \%$ & 77 & $89.5 \%$ & 0.367 & 288 & $91.4 \%$ \\
\hline $\begin{array}{l}\text { 3.I will follow the advice of this } \\
\text { physiotherapist or podiatrist because I } \\
\text { think she/he is right }\end{array}$ & 59 & $95.1 \%$ & 64 & $87.7 \%$ & 0.021 & 81 & $86.2 \%$ & 75 & $87.2 \%$ & 0.020 & 279 & $88.6 \%$ \\
\hline $\begin{array}{l}\text { 4.The time I was able to spend with the } \\
\text { physiotherapist or podiatrist was a bit too } \\
\text { short (R) }\end{array}$ & 46 & $74.2 \%$ & 61 & $83.6 \%$ & 0.807 & 68 & $81.0 \%$ & 59 & $68.6 \%$ & 0.333 & 234 & $74.3 \%$ \\
\hline $\begin{array}{l}\text { 5.The physiotherapist or podiatrist } \\
\text { explained the reasons for the advice given }\end{array}$ & 56 & $90.3 \%$ & 67 & $91.2 \%$ & 0.150 & 79 & $94.0 \%$ & 72 & $83.7 \%$ & 0.711 & 274 & $87.0 \%$ \\
\hline $\begin{array}{l}\text { 6.Some things about the consultation with } \\
\text { the physiotherapist or podiatrist could } \\
\text { have been better ( } R \text { ) }\end{array}$ & 46 & $74.2 \%$ & 53 & $63.0 \%$ & 0.166 & 68 & $72.3 \%$ & 60 & $69.8 \%$ & 0.120 & 227 & $72.1 \%$ \\
\hline $\begin{array}{l}\text { 7.The physiotherapist or podiatrist listened } \\
\text { very carefully to what I had to say }\end{array}$ & 57 & $91.2 \%$ & 68 & $93.2 \%$ & 0.344 & 79 & $94.0 \%$ & 74 & $86.0 \%$ & 0.330 & 278 & $88.3 \%$ \\
\hline $\begin{array}{l}\text { 8.I understand my treatment much better } \\
\text { after seeing the physiotherapist or } \\
\text { podiatrist }\end{array}$ & 54 & $87.1 \%$ & 54 & $74.0 \%$ & 0.025 & 68 & $72.3 \%$ & 61 & $70.9 \%$ & 0.164 & 237 & $75.2 \%$ \\
\hline $\begin{array}{l}\text { 9.The physiotherapist or podiatrist was } \\
\text { interested in me as a person not just my } \\
\text { illness }\end{array}$ & 50 & $80.1 \%$ & 56 & $76.7 \%$ & 0.033 & 77 & $81.9 \%$ & 65 & $75.6 \%$ & 0.152 & 248 & $78.7 \%$ \\
\hline $\begin{array}{l}10.1 \text { am NOT completely satisfied with the } \\
\text { advice received from this physiotherapist } \\
\text { or podiatrist (R) }\end{array}$ & 56 & $90.3 \%$ & 61 & $83.6 \%$ & 0.019 & 75 & $79.8 \%$ & 67 & $78.0 \%$ & 0.455 & 249 & $79.0 \%$ \\
\hline $\begin{array}{l}\text { 11.It was easy to make an appointment } \\
\text { with the physiotherapist or podiatrist }\end{array}$ & 35 & $56.5 \%$ & 49 & $67.1 \%$ & 0.900 & 74 & $78.7 \%$ & 60 & $69.8 \%$ & 0.028 & 218 & $69.2 \%$ \\
\hline $\begin{array}{l}\text { 12.There was an acceptable time lapse to } \\
\text { obtain an appointment }\end{array}$ & 30 & $48.4 \%$ & 43 & $58.9 \%$ & 0.759 & 67 & $71.3 \%$ & 57 & $66.3 \%$ & 0.378 & 197 & $62.5 \%$ \\
\hline $\begin{array}{l}\text { 13.It was possible to obtain an } \\
\text { appointment on a convenient day or hour }\end{array}$ & 40 & $64.5 \%$ & 49 & $67.1 \%$ & 0.695 & 70 & $74.5 \%$ & 62 & $72.1 \%$ & 0.067 & 221 & $70.2 \%$ \\
\hline $\begin{array}{l}\text { 14.I can contact someone in the service by } \\
\text { phone for help or advice in case of } \\
\text { problem }\end{array}$ & 38 & $61.2 \%$ & 47 & $64.4 \%$ & 0.881 & 70 & $74.5 \%$ & 56 & $65.1 \%$ & 0.020 & 211 & $67.0 \%$ \\
\hline $\begin{array}{l}\text { 15.In an emergency I can get a quick } \\
\text { appointment/consultation at this service }\end{array}$ & 19 & $30.6 \%$ & 25 & $34.2 \%$ & 0.177 & 60 & $63.8 \%$ & 36 & $41.9 \%$ & 0.001 & 140 & $44.4 \%$ \\
\hline $\begin{array}{l}\text { 16.I saw the physiotherapist or podiatrist at } \\
\text { the appointed time }\end{array}$ & 42 & $67.7 \%$ & 62 & $84.9 \%$ & 0.111 & 74 & $78.7 \%$ & 73 & $84.9 \%$ & 0.952 & 251 & $79.7 \%$ \\
\hline 17.The waiting time was acceptable & 45 & $72.5 \%$ & 64 & $87.7 \%$ & 0.088 & 80 & $85.1 \%$ & 71 & $82.6 \%$ & 0.494 & 260 & $82.5 \%$ \\
\hline
\end{tabular}

*p based on Mann Whitney $\mathrm{U}$ test using 5-point Likert Scale; for ease of interpretation, the table only displays for each item the number of patients who indicated a positive response (i.e. Strongly Agree/Agree or Strongly Disagree/Disagree for negatively paraphrased items (R)) - all corresponding percentages relate to the entire subgroup at the top of the column i.e. interpreting no response to the specific item as a lack of a positive response

(39.7\%) vs 37 out of 151 non-prescribing physiotherapist or podiatrist patients $(24.5 \%) ; p=0.005)$, with varying levels of satisfaction reported (see Table 6). Compared to patients of non-prescribing physiotherapist or podiatrists, patients of physiotherapist or podiatrist independent prescribers were significantly more likely to: 'be told when' and 'how often' to take their medicine, 'intend to take their medicines' and 'find it easier to follow the physiotherapists' advice' $(p \leq 0.05)$. 
Table 6 Patient views and experience of medicines management advice and information provided by physiotherapist or podiatrist

Patient views and
experience of
medicines management
advice and information
provided by
physiotherapist or
podiatrist

$\begin{array}{ll}\text { Physiotherapist } & \text { Physiotherapist } \\ \text { Independent } & \text { Non-prescriber } \\ \text { Prescriber } & (n=24) \\ (n=27) & \end{array}$

$(n=27)$

Strongly Agree/Agree

Mann-
Whitney
U-test

Non-prescriber

$(n=13)$

$(\mathrm{n}=31)$

Strongly Agree/Agree
Mann- Total

Whitney

U-test

\begin{tabular}{|c|c|c|c|c|c|c|c|c|c|c|c|c|c|}
\hline & \multirow[b]{2}{*}{$\begin{array}{l}\mathrm{N} \\
\text { (excluding } \\
\text { not } \\
\text { applicable }^{\mathrm{a}} \text { ) }\end{array}$} & \multirow[b]{2}{*}{$\bar{n}$} & \multirow[b]{2}{*}{$\%$} & \multirow[b]{2}{*}{$n$} & \multirow[b]{2}{*}{$\%$} & \multirow[b]{2}{*}{$\mathrm{p}^{*}$} & \multirow[b]{2}{*}{$\bar{n}$} & \multirow[b]{2}{*}{$\%$} & \multirow[b]{2}{*}{$n$} & \multirow[b]{2}{*}{$\%$} & \multirow[b]{2}{*}{$p^{*}$} & \multicolumn{2}{|c|}{ Agree } \\
\hline & & & & & & & & & & & & $\bar{n}$ & $\%$ \\
\hline $\begin{array}{l}\text { 1. The physiotherapist or } \\
\text { podiatrist gave me time } \\
\text { to clarify questions I may } \\
\text { have had about my } \\
\text { medicine }\end{array}$ & 84 & 24 & $96.0 \%$ & 19 & $86.4 \%$ & 0.627 & 21 & $84.0 \%$ & 11 & $91.7 \%$ & 0.901 & 75 & $89.3 \%$ \\
\hline $\begin{array}{l}\text { 2. The physiotherapist or } \\
\text { podiatrist told me when } \\
\text { to take my medicine }\end{array}$ & 64 & 11 & $73.3 \%$ & 6 & $40.0 \%$ & 0.030 & 19 & $82.6 \%$ & 9 & $81.8 \%$ & 0.719 & 45 & $70.3 \%$ \\
\hline $\begin{array}{l}\text { 3. The physiotherapist or } \\
\text { podiatrist told me how } \\
\text { often I should take my } \\
\text { medicine }\end{array}$ & 61 & 12 & $85.7 \%$ & 5 & $35.6 \%$ & 0.002 & 19 & $86.4 \%$ & 9 & $81.8 \%$ & 0.835 & 43 & $70.5 \%$ \\
\hline $\begin{array}{l}\text { 4. The physiotherapist or } \\
\text { podiatrist provided me } \\
\text { with information on the } \\
\text { purpose of my medicine }\end{array}$ & 75 & 16 & $73.7 \%$ & 14 & $70.0 \%$ & 0.547 & 19 & $82.6 \%$ & 11 & $84.6 \%$ & 0.549 & 60 & $80.0 \%$ \\
\hline $\begin{array}{l}\text { 5. The physiotherapist or } \\
\text { podiatrist provided me } \\
\text { with information on how } \\
\text { to use my medicine }\end{array}$ & 59 & 11 & $73.3 \%$ & 5 & $45.5 \%$ & 0.062 & 16 & $80.0 \%$ & 10 & $91.0 \%$ & 0.608 & 42 & $71.2 \%$ \\
\hline $\begin{array}{l}6 . \text { I expect that it will be } \\
\text { easy to follow the } \\
\text { physiotherapist's or } \\
\text { podiatrist's advice about } \\
\text { my medicine }\end{array}$ & 68 & 12 & $75.0 \%$ & 10 & $66.7 \%$ & 0.181 & 22 & $91.7 \%$ & 11 & $84.6 \%$ & 0.346 & 57 & $83.8 \%$ \\
\hline $\begin{array}{l}\text { 7. The physiotherapist or } \\
\text { podiatrist told me the } \\
\text { name of my medicine }\end{array}$ & 71 & 17 & $85.0 \%$ & 9 & $60.0 \%$ & 0.178 & 18 & $75.0 \%$ & 9 & $75.0 \%$ & 0.354 & 53 & $74.6 \%$ \\
\hline \multirow{3}{*}{$\begin{array}{l}\text { Patient views and } \\
\text { experience of } \\
\text { medicines management } \\
\text { advice and information } \\
\text { provided by } \\
\text { physiotherapist or } \\
\text { podiatrist }\end{array}$} & & \multicolumn{2}{|l|}{$\begin{array}{l}\text { Physiotherapist } \\
\text { Independent } \\
\text { Prescriber }\end{array}$} & \multicolumn{3}{|c|}{$\begin{array}{l}\text { Physiotherapist } \\
\text { Non-prescriber }\end{array}$} & $\begin{array}{l}\text { Podiatrist } \\
\text { Independent } \\
\text { Prescriber }\end{array}$ & & \multicolumn{2}{|c|}{$\begin{array}{l}\text { Podiatrist } \\
\text { Non- } \\
\text { prescriber }\end{array}$} & & \multicolumn{2}{|c|}{ Total } \\
\hline & & \multicolumn{5}{|c|}{ Strongly Agree/Agree } & \multicolumn{4}{|c|}{ Strongly Agree/Agree } & & \multicolumn{2}{|c|}{$\begin{array}{l}\text { Strongly } \\
\text { Agree/ } \\
\text { Agree }\end{array}$} \\
\hline & $\begin{array}{l}\mathbf{N} \text { (excluding } \\
\text { not } \\
\text { applicable }^{a} \text { ) }\end{array}$ & $\mathrm{n}$ & $\%$ & $\mathrm{n}$ & $\%$ & $\mathrm{p}^{*}$ & $\mathrm{n}$ & $\%$ & $\mathrm{n}$ & $\%$ & $\mathrm{p}^{*}$ & $\mathrm{n}$ & $\%$ \\
\hline $\begin{array}{l}\text { 8. The physiotherapist or } \\
\text { podiatrist explained the } \\
\text { side effects of my } \\
\text { medicine }\end{array}$ & 63 & 11 & $68.8 \%$ & 12 & $70.6 \%$ & 0.578 & 13 & $59.1 \%$ & 5 & $50.0 \%$ & 0.443 & 41 & $65.0 \%$ \\
\hline $\begin{array}{l}\text { 9. I would have liked to } \\
\text { have received more } \\
\text { information about my } \\
\text { medicine from the } \\
\text { physiotherapist or } \\
\text { podiatrist \# }\end{array}$ & 73 & 3 & $13.6 \%$ & 3 & $17.6 \%$ & 0.438 & 0 & $0.0 \%$ & 3 & $25.0 \%$ & 0.288 & 9 & $12.3 \%$ \\
\hline $\begin{array}{l}\text { 10. The physiotherapist } \\
\text { or podiatrist provided me } \\
\text { with information on what } \\
\text { to do if I missed a dose }\end{array}$ & 48 & 3 & $25.0 \%$ & 3 & $27.3 \%$ & 0.795 & 3 & $21.4 \%$ & 1 & $9.1 \%$ & 0.274 & 10 & $20.8 \%$ \\
\hline
\end{tabular}


Table 6 Patient views and experience of medicines management advice and information provided by physiotherapist or podiatrist (Continued)

\begin{tabular}{|c|c|c|c|c|c|c|c|c|}
\hline \multirow{3}{*}{$\begin{array}{l}\text { Patient views and } \\
\text { experience of } \\
\text { medicines management } \\
\text { advice and information } \\
\text { provided by } \\
\text { physiotherapist or } \\
\text { podiatrist }\end{array}$} & & $\begin{array}{l}\text { Physiotherapist } \\
\text { Independent } \\
\text { Prescriber } \\
(\mathrm{n}=27)\end{array}$ & $\begin{array}{l}\text { Physiotherapist } \\
\text { Non-prescriber } \\
(n=24)\end{array}$ & \multirow[t]{2}{*}{$\begin{array}{l}\text { Mann- } \\
\text { Whitney } \\
\text { U-test }\end{array}$} & $\begin{array}{l}\text { Podiatrist } \\
\text { Independent } \\
\text { Prescriber } \\
(n=31)\end{array}$ & $\begin{array}{l}\text { Podiatrist } \\
\text { Non-prescriber } \\
(n=13)\end{array}$ & \multirow[t]{2}{*}{$\begin{array}{l}\text { Mann- } \\
\text { Whitney } \\
\text { U-test }\end{array}$} & Total \\
\hline & & \multicolumn{2}{|c|}{ Strongly Agree/Agree } & & \multicolumn{2}{|c|}{ Strongly Agree/Agree } & & $\begin{array}{l}\text { Strongly } \\
\text { Agree/ } \\
\text { Agree }\end{array}$ \\
\hline & $\begin{array}{l}\text { N } \\
\text { (excluding } \\
\text { not } \\
\text { applicable }{ }^{a} \text { ) }\end{array}$ & $\mathbf{n}$ & $\%$ & $\mathbf{p}^{*}$ & $\mathbf{n}$ & n $\%$ & $\mathrm{p}^{*}$ & n $\%$ \\
\hline
\end{tabular}

of my medicine

11. It may be difficult for 56 me to do exactly what

the physiotherapist or podiatrist told me to do

in relation to my

medicine \#

12. I'm not sure it will be worth the trouble to take the medicine advised by the physiotherapist or podiatrist \#

13. Receiving a prescription for medicine from my physiotherapist or podiatrist reduced my waiting time today

14. I am likely to take the medicine prescribed

a those patients who did not respond "Yes" to the preceding question "During the consultation today, did the physiotherapist or podiatrist prescribe and/or give you advice and information about medicines(s)?"

${ }^{*} p$-value based on Mann Whitney $U$ test utilising the original 5 point Likert scale; for ease of interpretation, the table only displays for each item the number of patients who responded Strongly Agree/Agree

Note that for items labelled \# this may not be regarded as a positive response

\section{b) Quality of life- EQ-5D-L}

Indications at baseline were that patients who saw physiotherapist independent prescribers had lower generic quality of life than those seeing the non-prescribing physiotherapists, due to lower scores on the mobility dimension. However, there was no statistically significant difference between physiotherapist or podiatrist independent prescribers and non-prescribing physiotherapist or podiatrist groups on either individual items or overall EQ-5D-5Lscore $(p \geq 0.05)$ (Table 7, individual dimension scores not shown).

Quality of life overall scores in both physiotherapist and podiatrist independent prescribers and non-prescribing groups improved significantly between baseline and follow-up. Differences in change scores between the physiotherapist and podiatrist independent prescribers and non-prescribing physiotherapist or podiatrists, however, were not statistically significant (Table 7). The sample for which data at both time points were available was limited $(n=116)$.

\section{iv) iv. Economic analysis}

Amongst physiotherapists, the independent prescribers had significantly longer consultation duration than nonprescribers (27.6 vs $20.8 \mathrm{~min}$ ) (Table 8 ). Amongst podiatrists, the frequency with which medications i.e. a new medication, repeat medication (same dosage), or repeat medication (dosage changed) and tests were ordered were significantly higher in independent prescribers than non-prescribers (Table 8). There was a trend for consultation duration to be longer for independent prescribers (23.4 vs $19.9 \mathrm{~min}$ ) (Table 8).

Comparing physiotherapists and podiatrists, planning of follow up consultations was higher by podiatrist independent prescribers than physiotherapist independent prescribers, but no significant differences were found 
Table 7 Overall EQ. 5D index score: baseline and follow-up

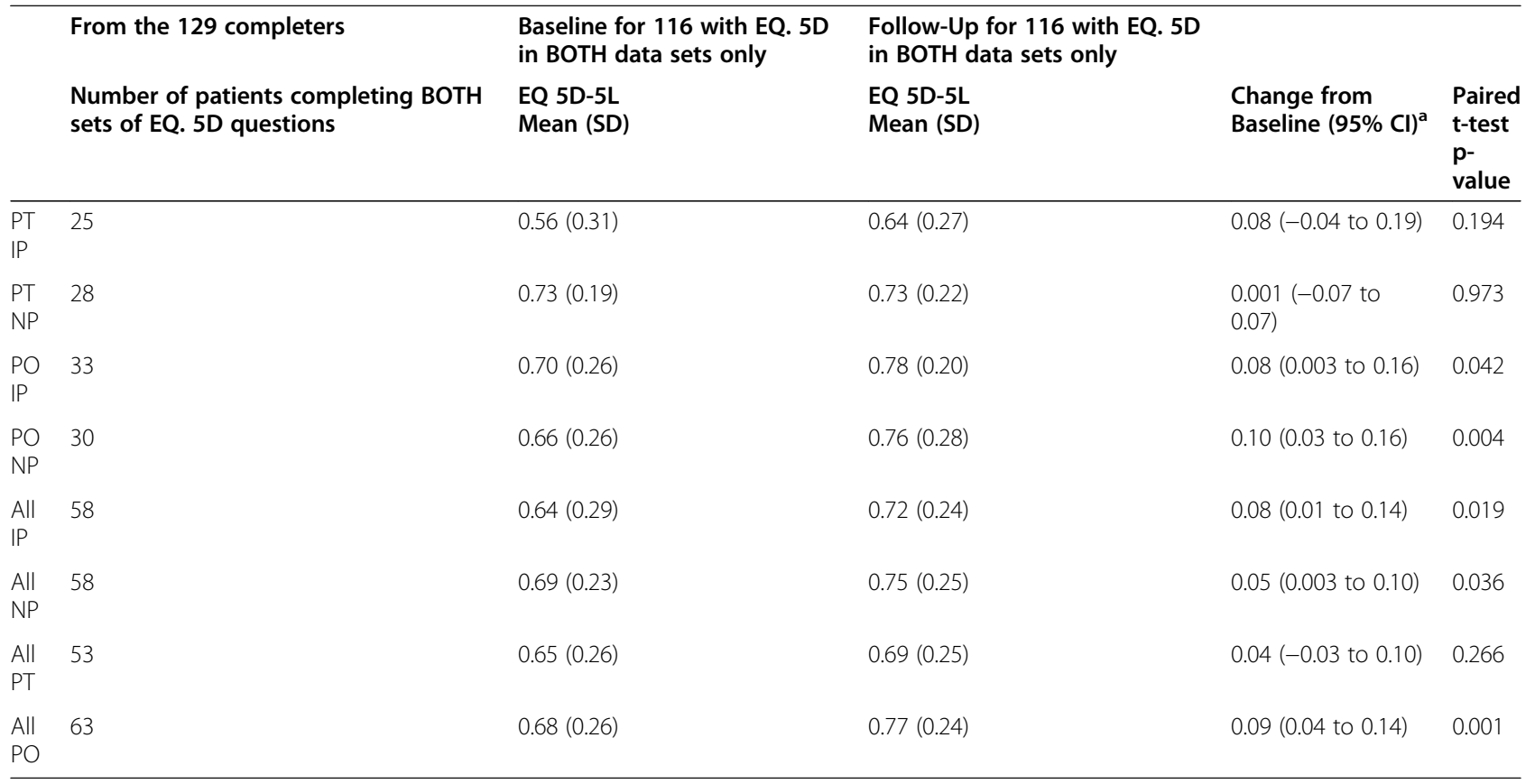

${ }^{\mathrm{a}}$ PPositive change indicates mean improvement in health at Follow-Up]

between independent prescribers and non-prescribers within the professions. After removing unplanned consultations in the two months after the original consultation that were considered (by two independent reviewers) to be unamenable to treatment delivered in the index consultation, only four items of unplanned service utilisation remained across the whole sample of patients of physiotherapists and podiatrists, all of which were related to pain relief (Table 8).

\section{Costs of consultations}

Difference in costs of consultation duration of independent prescribers compared to non-prescribers for physiotherapist and podiatrist groups were based on Agenda for Change (AfC) band 8a, which was the most frequent grade of physiotherapist and podiatrist independent prescribers in the study, i.e. $£ 70$ per hour [73]. Compared to the cost of a non-prescriber consultation, the independent prescriber consultation was, on average, more costly by $£ 7.95$ for physiotherapists ( $£ 24.30$ vs $£ 32.25$ ) and $£ 8.62$ ( $£ 19.69$ vs $£ 28.31$ ) for podiatrists. The salary of a grade 9 professional is twice that of grade $8 \mathrm{a}$, so at that higher level, the differences in the cost of consultations between independent prescribers and non-prescribers would be doubled. Use of grade 7 instead of grade $8 \mathrm{a}$ would reduce the differences between independent prescribers and non-prescriber by about $£ 1.20$ per consultation. Amongst the podiatrists, the independent prescribers were at band 7 (advanced / team leader), 8a (principal) and 9 (consultant); two of the non- prescribers were band 9 and the third was band 6 (specialist). Participating physiotherapists were all band $8 \mathrm{a}$, except one non-prescriber (grade 8c), and one independent prescriber (grade 7).

Costs could not be estimated for the other elements of activity that might differ between independent prescribers and non-prescribers due to data availability problems. Information on tests ordered were drawn from a small sample of records $(\mathrm{n}=\max 15$ per site) in each site (the audit); reporting of the type and dose of new medications, referrals and frequency of planned follow up was incomplete.

\section{Discussions with colleagues}

The independent prescribers in the physiotherapist group consulted colleagues about patients significantly more often than the non-prescribers $(17.8 \%$ vs $0.9 \%$ of consultations), and most discussions were with medical colleagues, averaging $9.5 \mathrm{~min}$ per discussion (Table 9).

Podiatrists held discussions with colleagues for $>10 \%$ of consultations (14.8\% IPs, $10.5 \%$ NPs, (Table 9)), for around $7 \mathrm{~min}$. Independent prescribers discussed a higher proportion of patients with medical colleagues, than a colleague from the same profession, thereby likely to be incurring higher costs. However, information on colleagues consulted was not precise, so calculations were indicative only. Some podiatrists were band 9 (consultant), so reporting discussions with 'same' professional would imply higher costs than are indicated in the table, which are based on AfC band 8a. 


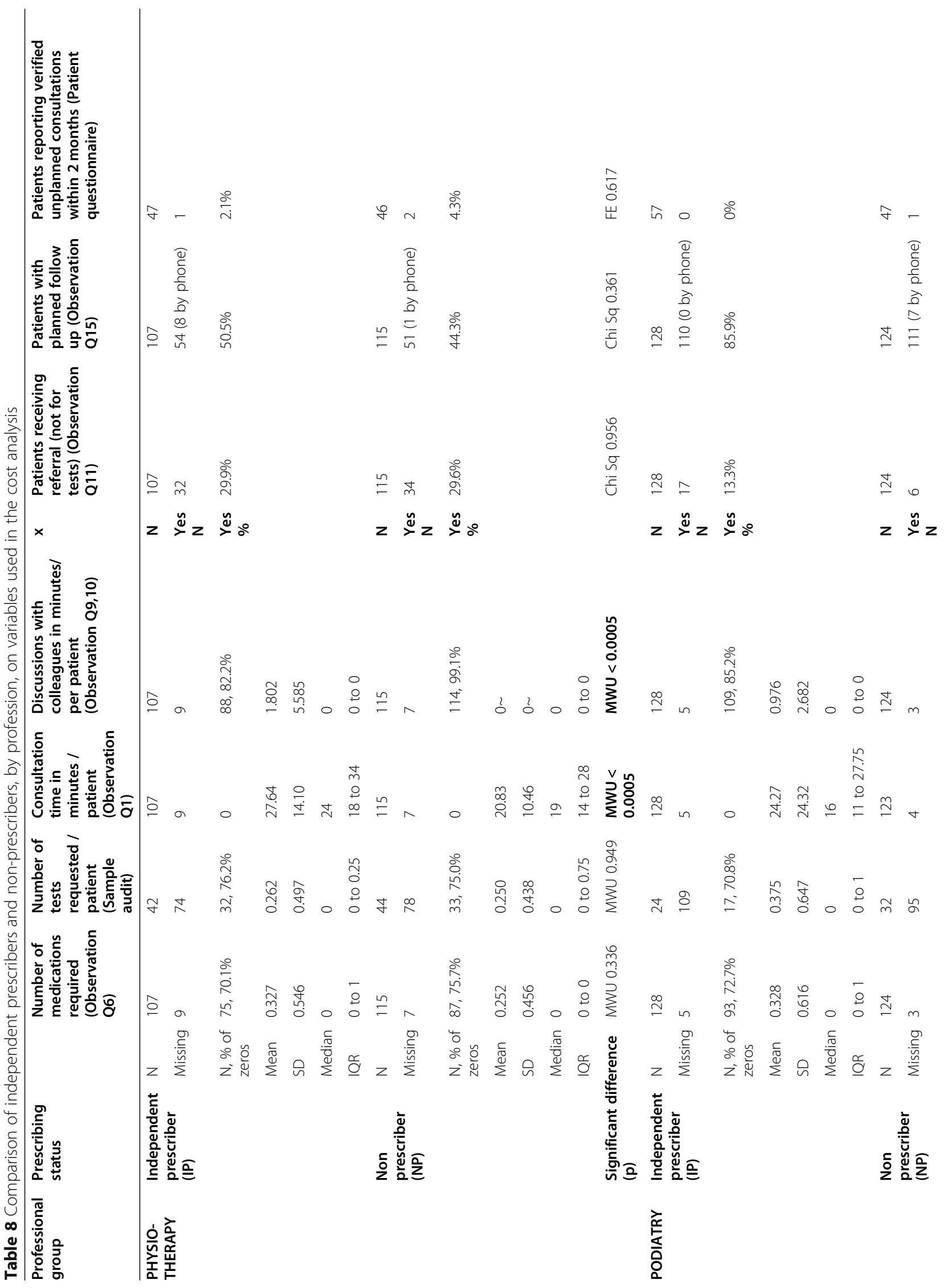




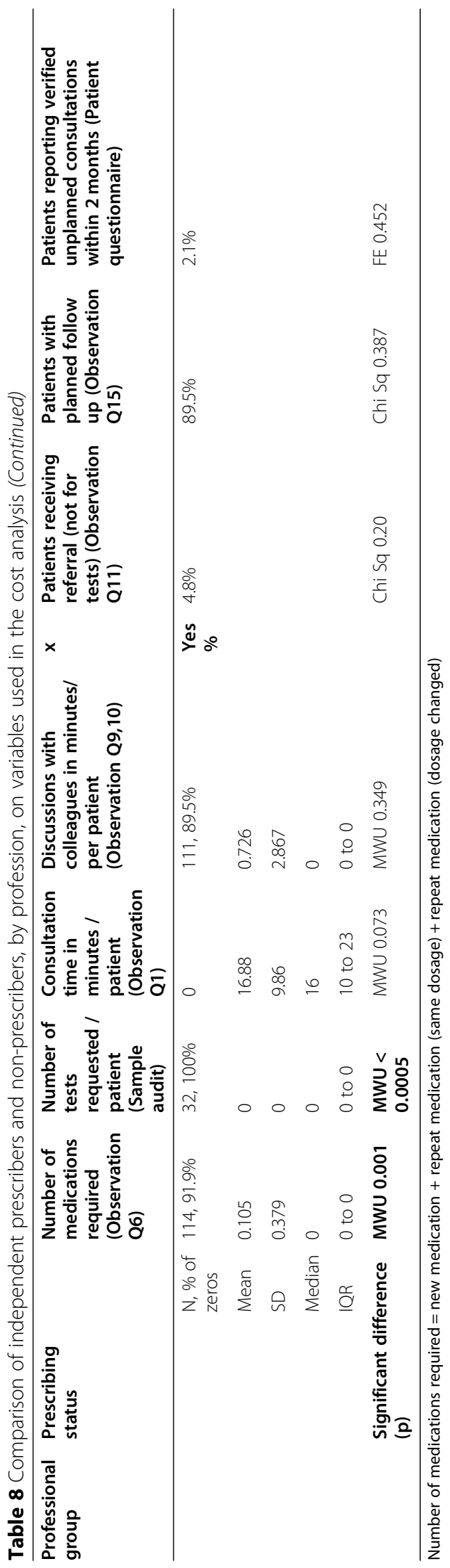


Table 9 Discussion with colleagues about patient

\begin{tabular}{|c|c|c|c|c|c|c|c|}
\hline $\begin{array}{l}\text { Professional } \\
\text { group }\end{array}$ & $\begin{array}{l}\text { Prescribing } \\
\text { status }\end{array}$ & $\begin{array}{l}\text { Number and \% of all patients } \\
\text { seen for whom discussion } \\
\text { occurred with colleague }\end{array}$ & $\begin{array}{l}\text { Mean (SD) minutes } \\
\text { in discussions with } \\
\text { colleague } \\
\text { per patient }\end{array}$ & $\begin{array}{l}\text { Discussion } \\
\text { with same } \\
\text { professional } \\
\mathrm{n} \text {, mean } \\
\text { (SD) } \\
\text { minutes }\end{array}$ & $\begin{array}{l}\text { Same } \\
\text { colleague } \\
\text { cost } / \\
\text { discussion } \\
(£, 2015)\end{array}$ & $\begin{array}{l}\text { Discussion } \\
\text { with } \\
\text { medical } \\
\text { professional } \\
\mathrm{n}, \text { mean } \\
\text { (SD) } \\
\text { minutes }\end{array}$ & $\begin{array}{l}\text { Medical } \\
\text { colleague cost } \\
\text { / discussion }{ }^{b} \\
(£, 2015)\end{array}$ \\
\hline \multirow[t]{3}{*}{$\begin{array}{l}\text { PHYS } \\
\text { IOTHERAPY }\end{array}$} & $\begin{array}{l}\text { Independent } \\
\text { prescriber }\end{array}$ & 19 (17.8\%) & 10.61 (9.68) & $3,19.5(14.8)$ & $£ 22.75$ & $16,9.5(8.9)$ & $£ 21.69$ \\
\hline & $\begin{array}{l}\text { Non } \\
\text { prescriber }\end{array}$ & $1(0.9 \%)$ & 0 (n/a) & $\begin{array}{l}\text { 1, time } \\
\text { missing }\end{array}$ & Not known & $0, \mathrm{n} / \mathrm{a}$ & 0 \\
\hline & $\begin{array}{l}\text { Significant } \\
\text { difference }\end{array}$ & $p<0.0005^{a}$ & $\mathrm{n} / \mathrm{a}$ & & & & \\
\hline \multirow[t]{3}{*}{ PODIATRY } & $\begin{array}{l}\text { Independent } \\
\text { prescriber }\end{array}$ & 19 (14.8\%) & $6.89(3.20)$ & $11,6.8(3.6)$ & $£ 7.93$ & $8,7.0(2.8)$ & $£ 15.98$ \\
\hline & $\begin{array}{l}\text { Non } \\
\text { prescriber }\end{array}$ & $13(10.5 \%)$ & $6.92(6.14)$ & $12,7.3(6.3)$ & $£ 8.52$ & 1, $3.0(0.0)$ & $£ 6.85$ \\
\hline & $\begin{array}{l}\text { Significant } \\
\text { difference }\end{array}$ & $p=0.299 \sim$ & $p=0.493 \wedge$ & & & & \\
\hline
\end{tabular}

${ }^{a}$ Fishers Exact test; $\sim$ Chi squared test; $\wedge$ Mann Whitney $U$ test

bUnit costs of health and social care 2015 (Curtis and Burns 2015), pro rata based on $£ 70 / \mathrm{h}$ for same professional i.e. AfC band $8 a$, as in Ec2 above, and $£ 137 / \mathrm{h}$ for medical consultant

\section{Cost implications}

The available data suggest that for both physiotherapists and podiatrists in this study, care delivery by independent prescribers is more resource intensive and costly than non-prescribers due to longer consultations for physiotherapists and taking more time of colleagues to discuss patients. Whilst not costed, podiatrist independent prescribers had higher frequency of ordering medications and tests than non-prescribing podiatrists. Analysis of the changes in self-reported health status between baseline and 2 months follow up using EQ-5D-5L found no difference in change scores of independent prescribers and non-prescribers for either physiotherapists or podiatrists, but these data were only available for a small sample of participants.

\section{Discussion}

This is the only known national evaluation of physiotherapist and podiatrist independent prescribers in the UK or the world, and the first to adopt a comparative case study design to compare outcomes and costs for patients managed by physiotherapist and podiatrist independent prescribers/ non-prescribers. Unlike nurses and pharmacists, where prescribing has been explored in some detail using self-reported outcomes [26, 47, 70], there is a dearth of equivalent information in the allied health professions, including either physiotherapy and/ or podiatry $[29,35]$ and/ or studies adopting direct observation of outcomes [26]. Our study demonstrates that care provided by physiotherapist and podiatrist independent prescribers is equivalent, in terms of quality of life and patient satisfaction, to care provided by non- prescribing physiotherapists with prescribing undertaken by doctors. Independent prescribing by physiotherapists and podiatrists was found to be effective, and highly acceptable, with higher levels of patient satisfaction in some aspects of medicines information also reported than for non- prescribers.

Importantly, it appears that physiotherapist and podiatrist independent prescribing is developing in line with original policy intention to improve access to medicines and quality of care across a range of settings [74-76]. The evidence generated in this study demonstrates that physiotherapist and podiatrist independent prescribers can provide a high standard of care. Extending nonmedical staff, such as physiotherapists' and podiatrists', scope of practice to include independent prescribing is key to supporting effective delivery of the NHS Long Term Plan $[9,49,77]$, and creating a step change in developing the capacity and capability of the workforce to deliver innovative models of service delivery $[4,9]$. The severity of the workforce deficit makes changes, such as the increased level of clinical autonomy, associated with independent prescribing an attractive option to commissioners who seek to address gaps in service delivery. As the world leader in extending prescribing rights to nurses, pharmacists and allied health professions the findings are of significant importance to international policy makers who seek to learn from the pioneering advancement of prescribing rights in $\operatorname{UK}[25,28]$ to inform their own approach to addressing the workforce deficit.

Internationally it is now common for physiotherapists, nurse practitioners, pharmacists, social workers, and psychiatric nurses to be located within extended primary 
care teams [78] with plans to extend this further recently announced $[9,11]$. Nearly $50 \%$ of appointments in UK general practice are for example, already provided by non-medical staff, i.e. nurses, pharmacists and allied health professionals $[9,79]$. In addition to the current shortage of 2500 general practitioners, this is important for several reasons: i) the current deficit in primary care looks set to continue [80, 81]; ii) the recent proposal for home visits to be removed from the GP contract, and iii) the government pledge to create 50 million more GP appointments year by $2024 / 25$ [81, 82]. As the third largest workforce in health and care in England, allied health professionals have, through the introduction of a further 20,000 non-doctor roles in primary care [83], great potential to contribute to transforming care and ensuring ongoing access to medicines [11].

Having a robust economic evaluation of physiotherapist and podiatrist independent prescribing is particularly important, given that identifying a sustainable solution that i) improves the worldwide deficit of health workers, and ii) makes best use of limited resources is essential to ensuring ongoing access to medicines [9, 11]. Our cost appraisal from the case sites suggests that physiotherapist and podiatrist independent prescriber care delivery is more resource intensive than non-prescribing physiotherapists and podiatrists. This arises through longer consultation duration, more ordering of medicines and tests (podiatrists) and more discussions with colleagues (physiotherapists). These costs, however, need to be considered in relation to benefits, particularly clinical outcomes, many of which could not be measured in this study. Only a limited economic analysis was possible meaning that the findings should be treated with caution. Whilst the original intention had been to undertake a patient level micro costing analysis, data deficiencies limited what could be included. Further research is required to understand how team configuration affects care delivery, patient outcomes and costs.

The most complete data were available for consultation duration, and the calculation of associated costs showed independent prescribers to incur slightly higher consultation costs than non-prescribers in both the podiatrist and physiotherapist groups ( $£ 8.62$ and $£ 7.95$ respectively). It is important to note however that consultation duration and associated costs may simply be driven by professional differences and clinic practices. The complexity of these arrangements means that the differences in cost could equally reflect service differences which would exist regardless of independent prescribing status. Furthermore, the time spent in discussion with colleagues may reflect the multiprofessional service that many case sites provided. Multi-professional, or team-working is a fundamental component of health care delivery in the UK and central to current government policy [84-86]. There is increasing emphasis on establishing systems, rather than single episodes of care, that dissolve traditional boundaries [87, 88] to support the increasing number of people with long-term conditions.

There is limited evidence available with which to compare our study findings [26, 35, 45, 46, 89]. Despite positive findings that non-medical prescribing is safe, and provides beneficial clinical outcomes [26, 28, 70], the impact on the health economy, as reported in two recent systematic reviews examining clinical and cost effectiveness, remains unclear $[45,46,89]$. The authors, as in this study, highlight the difficulty in separating non-medical prescribing effects from the contributions of healthcare team members, and a lack of adequately powered randomised controlled trials examining non-medical prescribing across clinical specialities, professions and settings $[25,45]$. Given that extended prescribing rights to nurses, pharmacists and allied health professions offers a sustainable approach to improving the global workforce deficit, there is a pressing need to establish economic benefits, or otherwise of non-medical prescribing to inform future international policy developments. A different approach, involving highly targeted specific outcomes, and or longitudinal studies is therefore required. The development of a minimum data set of important outcome measures for non-medical prescriber assessment would as Noblet et al. suggests [45], be highly beneficial, and generate the required evidence to evaluate the overall benefit of non-medical prescribing and inform future developments in the UK and around the world.

\section{Strengths and limitations}

In the first study to explore allied health professional prescribing, the 14 case sites supported an in-depth evaluation and comparison of physiotherapist and podiatrist independent prescribers to non-prescribers in a range of care settings. Use of multiple methods of data collection, including an observational component, strengthens the trustworthiness of the findings. Physiotherapist and podiatrist independent prescriber participants were selected from a larger sample $(n=70)$ who completed a trainee physiotherapist and podiatrist independent prescriber survey and indicated that they would be willing to be involved in further research [52].

Despite challenges in matching sites, given the diversity of service settings, roles, and patient needs, between and within the two professions, patient characteristics indicated good matching on most factors. For future research, matching at a patient/condition level would ensure a comparative sample. Additionally, as patients were predominantly retired, house owners, and lacked ethnic diversity, reflecting study locations, caution must 
be applied with respect to generalizing the findings to other groups of the population. Furthermore, there are limitations and methodological challenges associated with using the same evaluation measures on two different professional groups for whom separate measures might have been more appropriate. The economic analysis was constrained as described above. An analysis of effectiveness was not possible because it was not feasible to collect data on specific indicators for change across the wide variety of conditions treated within physiotherapist and podiatrist consultations. Our ability to link each of the various aspect of patient data (i.e. observation, questionnaires, record audit) was also very limited as patients, in line with good ethical practice, had the option to select which aspects of data collection they agreed to. As a result, it was not possible to match patients across the different data sets, or to complete some of the intended analysis.

\section{Conclusions}

This study provides new knowledge about physiotherapist and podiatrist independent prescribing, the high level of care and patient satisfaction they provide. Given that extending prescribing responsibilities to nurses, pharmacists, and allied health professionals is increasingly being recognised as effective way to alleviate shortfalls in the global health workforce and ensure ongoing access to prescription medicines around the world this is important. PP-IP care delivery was found to be more resource intensive than NP-PP. However, this study is limited, and findings needs to be verified through further research, including a full economic analysis. A more focussed longitudinal exploration within each profession with targeted outcome measures would enable a more robust comparison of the impact of physiotherapist and podiatrist independent prescribing across the United Kingdom and inform further developments around the world.

\footnotetext{
Abbreviations

A\&E: Accident and Emergency; BP: Blood pressure; BNF: British National Formulary; CT: Computerised tomography; EQ 5-D: EuroQol 5-D; GP: General Practitioner; MMA: Medicines Management Activities; MRI: Magnetic Resonance Imaging; NMP: Non- medical prescriber; NP-PP: NON-prescribing Physiotherapist \& Podiatrist; OTC: Over the counter; PGD: Patient Group Direction; PO-IP: Podiatrist independent prescriber; PO-NP: Podiatrist nonprescriber; PP: Physiotherapist \& Podiatrist; PP-IP: Physiotherapist \& Podiatrist Independent Prescriber; PSD: Patient Specific Direction; PT-IP: Physiotherapist independent prescriber; PT-NP: Physiotherapist non-prescriber
}

\section{Acknowledgements}

We would like to thank the physiotherapists and podiatrists, team members, patients and stakeholder participants who took part in our study, and our project advisory group and patient public involvement group for their advice and contributions throughout. Special thanks to assistance from Clareece Kerby, with data preparation and analysis, and Emma Konstantara with recruitment in private healthcare settings.

\section{Authors' contributions}

NC was overall project lead with responsibility for execution of the study. All authors: NC; KS; JE; MC; SO, AM, HG, PW contributed to the design of the study. JE undertook data collection. HG and PW undertook analysis of heath economics data. PW provided expertise on data analysis. All authors (NC; KS; JE; MC; SO, AM, HG, PW) participated in interpretation of data. NC \& KS drafted the manuscript. All authors (NC; KS; JE; MC; SO, AM, HG, PW) read, commented on and approved the final manuscript.

\section{Funding}

This work was funded by Department of Health Policy Research Programme (PRP) grant number: PR-R19-0617-21001. The funding body had no role in the design of the study, collection, analysis, and interpretation of data nor in writing the manuscript. The views expressed in this article are those of the author(s) and not necessarily those of the NHS, the PRP or the Department of Health.

\section{Availability of data and materials}

The study did not receive ethics approval, or participant consent, to place a study dataset in the public domain. The data, and tools used for its collection in this study can be made accessible to qualified researchers upon reasonable request pursuant to any restrictions required to ensure the privacy of human subjects involved. Access to data will be subject to a data sharing agreement approved by University of Surrey. Researchers interested in accessing USEFUL data should send their request to the Director of Research, Professor Emma Ream (e.ream @surrey.ac.uk).

\section{Ethics approval and consent to participate}

NHS Research Ethics approval from London - Surrey Borders Research Ethics Committee was (REC Ref No 14/LO/1874) and the University was obtained. R\&D approval was obtained from each National Health Service (NHS) trust and private healthcare providers. All participants provided written informed consent form for the various aspects of data collection.

\section{Consent for publication}

Not applicable.

\section{Competing interests}

The authors declare that they have no competing interests.

\section{Author details}

'School of Health Sciences, University of Surrey, Kate Granger Building, Guildford GU2 7YH, UK. ${ }^{2}$ School of Health Science, University of Brighton, Brighton, UK. ${ }^{3}$ Department of Clinical and Experimental Medicine, Surrey Health Economics, University of Surrey, Guildford, UK. ${ }^{4}$ Department of Mathematics, Faculty of Engineering and Physical Sciences, University of Surrey, Guildford, UK. ${ }^{5}$ School of Healthcare Sciences, Cardiff University, Cardiff, UK

Received: 19 May 2020 Accepted: 12 November 2020 Published online: 24 November 2020

\section{References}

1. GBD 2016 Disease and Injury Incidence and Prevalence Collaborators. Global, regional, and national incidence, prevalence, and years lived with disability for 328 diseases and injuries for 195 countries, 1990-2016: a systematic analysis for the Global Burden of Disease Study 2016. Lancet. 2017:390:1211-59.

2. Marengoni A, Angleman S. R M. aging with multimorbidity: a systematic review of the literature. Ageing Res Rev. 2011;10:430-9.

3. OECD. Health at a Glance 2019 OECD Indicators. Paris: OECD Publishing; 2019. ( http://www.oecd.org/health/health-systems/health-at-a-glance-1 9991312.htm accessed 3rd August 2020).

4. World Health Organisation. The World Medicines Situation Report. https:// www.whoint/medicines/areas/policy/world_medicines_situation/en/ accessed 15th August 2019. 2011.

5. Centers for Disease Control and Prevention. Therapeutic Drug Use. https:// www.cdcgov/nchs/fastats/drug-use-therapeutichtm accessed 15th August 2019. 2017.

6. NHS Digital. Health Survey for England 2016. http://healthsurveyhscicgovuk media/63790/HSE2016-pres-medpdf accessed 15th August 2019. 2017. 
7. IMS Institute for Healthcare Informatics. Global Medicines Use in 2020: Outlook and Implications. https://wwwiqviacom/-/media/iqvia/pdfs/ institute-reports/global-medicines-use-in-2020pdf?la=uk-ua\&hash= 968B71C0B0769A179F3A56E331C62754EEF74752 accessed 15th August 2019. 2015.

8. WHO. Working for health and growth: investing in the health workforce. Report of the High-Level Commission on Health Employment and Economic Growth. Geneva: World Health Organization; 2016.

9. Beech J, Bottery S, Charlesworth A, Evans H, Gershlick B, Hemmings N, et al. Closing the gap: Key areas for action on the health and care workforce: The Health Foundation; The Kings Fund \& Nuffield Trust 2019.

10. World Health Organisation. Global strategy on human resources for health: workforce 2030. https://www.who.int/hrh/resources/globstrathrh-2030/en/: World Health Organisation; 2016.

11. Chief Allied Health Professions Officers's Team. AHPs into action. Using allied health professions to transform health, care and wellbeing. London: Chief Allied Heath Professions Officer's Team, NHS England; 2017.

12. DH. Allied Health Professions Prescribing and medicines supply mechanisms scoping project report. London: Department of Health; 2009.

13. DH. A High Quality Workforce: NHS Next Stage Review: Our vision for primary and commmunity health care. London: $\mathrm{DH} ; 2008$.

14. DH. Equity and excellence:liberating the NHS. London: DH; 2010.

15. DH. Meeting the challange: a strategy for the allied health professions. London: $\mathrm{DH} ; 2000$

16. DH. Framing the contribution of allied health professions: delivering high quality healthcare. London: $\mathrm{DH} ; 2008$.

17. Hogg D. Prescription, supply and administration of medicines by allied health professionals- where are we now and where are we going? South West House Taunton TA1 2PX: Regional AHP Non-Medical Prescriber Forum: April 11th 2019. 2019.

18. NMC. Standards for prescribing programmes. https://wwwnmcorguk/ globalassets/sitedocuments/education-standards/programme-standardsprescribingpdf 2018;accessed July 2020.

19. HCPC. Standards for Prescribing. https://wwwhcpc-ukorg/globalassets/ standards/standards-for-prescribing/standards-for-prescribing2pdf. 2019; acessed July 2020

20. General Pharmaceutical Council. In: GPhC, editor. Standards for the education and training of pharmacist independent prescribers. London: GpHC; 2019 .

21. DH. Proposals to introduce independent prescribing by physiotherapists: Impact Assessment. London: DH; 2012.

22. DH. Summary of Public Consulation on proposals to introduce independent prescribing by Physiotherapists. London: Allied Health Professions Team, DH; 2012.

23. $\mathrm{DH}$. Consultation on proposals to introduce independent prescribing by physiotherapists and podiatrists. London: https://www.gov.uk/government/ news/proposals-to-introduce-independent-prescribing-for-physiotherapistsand-podiatrists2011. Accessed 5 Jan 2020.

24. DH. Supplementary Prescribing by Nurses, Pharmacists, Chiropodists, Podiatrists, Physiotherapists and Radiographers within NHS in England. A Guide for Implementation. London: DH; 2005.

25. Stewart D, Jebara T, Cunningham S, Awaisu A, Pallivalapila A, MacLure K. Future perspectives on nonmedical prescribing. Ther Adv Drug Saf. 2017; 8(6):186-97.

26. Weeks G, George J, Maclure K, Stewart D. Non-medical prescribing versus medical prescribing for acute and chronic disease management in primary and secondary care. Cochrane Database Syst Rev. 2016;11:Cd011227.

27. Wilson DM, Murphy J, Nam MA, Fahy A, S T. Nurse and midwifery prescribing in Ireland: A scope-ofpractice development for worldwide consideration. Nurs Health Sci. 2018;20:264-70. https://doi.org/10.1111/nhs. 12408.

28. Kroezen M, Van Dijk L, Groenewegen PP, Francke AL. Nurse prescribing of medicines in Western European and Aglo-Saxon, countries: a systematic review of the literature. BMC Health Serv Res. 2011;11(127). https://doi.org/ 10.1186/472-6963-11-27.

29. Stenner K, Edwards J, Mold F, Otter S, Courtenay M, Moore A, et al. Medicines management activity with physiotherapy and podiatry: a systematic mixed studies review. Health Policy. 2018;122(12):1333-9 doi: 10. 016/j.healthpol.2018.10.004.

30. Noblet T, Marriot J, Jones T, Dean C, Rushton A. Views and perceptions of Australian physiotherapists and physiotherapy students about the potential implementation of physiotherapist prescribing in Australia: a survey protocol. BMC Health Serv Res. 2018;14(472). https://doi.org/10.1186/s12913018-3300-X.

31. Stanhope J, Grimmer-Somers K, Milanese S, Kumar S, Morris J. Extended scope physiotherapy roles for orthopedic outpatients: an update systematic review of the literature. J Multidiscip Healthc. 2012;5:37-45.

32. Bissell P, Cooper R, Guillaume L, Anderson C, Avery A, Hutchinson A, et al. An Evaluation of Supplementary Prescribing in Nursing and Pharmacy: University of Sheffield \& University of Nottingham \& Flinders University \& University of South Australia 2008.

33. Norman I, While A, Whittlesea C, Coster S, Sibley A, Rosenbloom K, et al. Evaluation of mental health nurse supplementary prescribing. London: Florence Nightingale School of Nursing and Midwifery at King's College London; 2017.

34. Latter S, Blenkinsopp A, Smith A, Chapman S, TInelli M, Gerard K, et al. Evaluation of nurse and pharmacist independent prescrbing: Department of Health Policy Research Programme: University of Southampton \& Keele University 2010.

35. Graham-Clarke E, Rushton A, Noblet $T$, J M. Facilitators and barriers to nonmedical prescribing - A systematic review and thematic synthesis. PloS one. 2017;13(4):e0196471. https://doi.org/10.1371/journal.pone.0196471.

36. Kersten P, McPherson K, Lattimer V, George S, Breton A, Ellis B. Physiotherapy extended scope of practice-who is doing what and why? Physiotherapy. 2007:93:235-42.

37. McPherson K, Kersten P, George S, Lattimer V, Breton A, Ellis A, et al. A systematic review of evidence about extended roles for allied health professions. J Health Serv Res Policy. 2006;11(240):240-7.

38. Ramaswamy B. Physiotherapist supplementary prescriber reducing hospital stays duration in an intermediate care, therapy-led bed service: example of implementation of NMP. Derby: Derbyshire Community Health Services: 2009

39. Popadiuk S, Rhajbhandari S. Benefits of non-medical prescribing within an NHS podiatry service. J Foot Ankle Res. 2010;3(1):20.

40. Carey N, Stenner K, Courtenay M. Stakeholder views on the impact of nurse prescribing on dermatology services. J Clin Nurs. 2010;19:498-506.

41. Courtenay M, Stenner K, Carey N. An exploration of the practice of nurse prescribers who care for people with diabetes: a case study. J Nurs Healthc Chronic IIIn. 2009:1:311-20.

42. Stewart D, Jebara T, Cunningham S, Awaisu A, Pallivalapila A, MacLure K. Future perspectives on nonmedical prescribing. Ther Adv Drug Saf. 2017 Jun;8(6):183-97.

43. Courtenay M, Carey N, Gage H, Stenner K, Williams P. A comparison of prescribing and non-prescribing nurses in the management of people with diabetes. J Adv Nurs. 2015;71(12):2950-64.

44. Carey N, Stenner K, Edwards J, Gage H, Williams P, Otter S, et al. Evaluation of physiotherapist and podiatrist independent prescribing, mixing of medicines and prescribing of controlled drugs. Guildford: Uiversity of Surrey; 2017. Contract No.: PR-R7-0513-11002.

45. Noblet T, Marriott J, Graham-Clarke E, Shirley D, Alison RA. Clinical and costeffectiveness of non-medical prescribing: a systematic review of randomised controlled trials. PLoS One. 2018;13(3):e0193286. https://doi.org/10.1371/ journal.pone.

46. Anthony BF, Surgey A, Hiscock J, Nefyn H, Williams NH, Charles JM. General medical services by non-medical health professionals: a systematic quantitative review of economic evaluations in primary care. $\mathrm{Br} J$ Gen Pract. 2019;69(682):e304-e13. https://doi.org/10.3399/bjgp19X702425.

47. Hogg D. An economic evaluation of non-medical prescribing: Association of Prescribers Annual Conference. London: Holiday Inn Regents Park; 2016.

48. HCPC. Number of Physiotherapist and Podiatrist Independent Prescribers. 2020 https://wwwhcpc-ukorg/about-us/insights-and-data/the-register/ registrant-snapshot-1-oct-20202/ accessed 25th October 2020.

49. Imison C, Castle-Clarke S, Watson R. Reshaping the workforce to deliver the care patients need. 2016 https://www.nuffieldtrust.org.uk/research/ reshaping-the-workforce-to-deliver-the-care-patients-need accessed 27th August 2019: Nuffield Trust.

50. Weiss C. Program theory in evaluation: challenges and opportunities, new directions for evaluation. San Fransisco: Jossey Bass; 2000.

51. Stern E, Stame N, Mayne J, Forss K, Davies R, Befani B. Broadening The Range Of designs and Methods for Impact Evaluations. London: Report of a Study Commissioned by the Department For International Development; 2012 
52. Carey N, Stenner K, J E, Gage H, Williams P, Otter S, et al. Evaluation of Phsyiotherapist and Podiatrist Independent Prescribing, Mixing of Medicines, and Prescribing of Controlled Drugs: Final Report. https://www. surrey.ac.uk/evaluation-physiotherapy-podiatrist-independent-prescribingmixing-medicine-and-prescribing accessed 27th August 2019: University of Surrey, University of Brighton and University of Cardiff 2017.

53. Wolf $M$, Putnam S, James $A$, Stiles $W$. The medical interview satisfaction scale: development of a scale to measure patient perceptions of physician behavior. J Behav Med. 1978;1:301-401.

54. Meakin R, Weinman J. The medical interview satisfaction scale (MISS-21) adapted for British general practice. Fam Pract. 2002;19(3):257-63.

55. Horne R, Hankins M, Jenkins R. The satisfaction with information about medicines scale (SIMS): a new measurement tool for audit and research. Quality in Health Care. 2001;10:135-40.

56. Drennan J, Naughton C, Allen D, Hyde A, Felle P, O'Boyle K, et al. Independent Evaluation of the Nurse and Midwife Prescribing Initiative. Dublin: University College Dublin; 2009.

57. Poulton B. Use of the consultation satisfaction questionnaire to examine patients' satisfaction with general practitioners and community nurses: reliability, replicability, and discriminant validity. Br J Gen Pract. 1996;46:26-31.

58. Gasquet I, Villeminot S, Estaquio C, Durieux P, Ravaud P, Falissard B. Construction of a questionnaire measuring outpatients' opinion of quality of hospital consultation departments. Health Qual Life Outcomes. 2004;4(2):43.

59. Latter S, Maben J, Myall M, Courtenay M, Young A, Dunn N. An evaluation of extended formulary independent nurse prescribing. Final Report: Policy Research Programme Department of Health \& University of Southampton; 2005

60. Herdman M, Gudex C, Lloyd A, Janssen MF, Parkin D, Bonsel G, et al. Development and preliminary testing of the new five-level version of EQ-5D (EQ-5D-5L). Qual Life Res. 2011;20(10):1727-36.

61. Courtenay M, Carey N, Stenner K. Evaluation of Nurse Independent Supplementary Prescribing in the UK: Interim Report: University of Surrey; 2010

62. Latter S, Sibley A, Skinner TC, Craddock S, Zinken KM, Lussier MT, et al. The impact of an intervention for nurse prescribers on consultations to promote patient medicine-taking in diabetes: A mixed methods study. Int J Nurs Stud. 2010. https://doi.org/10.1016/ijnurstu.2010.02.004

63. Sherrington S, Bell D. Quality, innovation, productivity and prevention through non-medical prescribing. Pharmacoepidemiol Drug Safety. 2011;20: 660-7. https://doi.org/10.1002/pds.

64. Britten N, Jenkins L, Barber N, Bradley C, Stevenson F. Developing a measure for the appropriateness of prescribing in general practice. Qual Safety Health Care. 2003;12:246-50.

65. Courtenay M, Carey N. The completeness of prescriptions issued to dermatology patients by nurse prescribers. Nurse Prescribing. 2008;6(9):391-6.

66. Carey N, Stenner K, Courtenay M. Prescription writing for patients with diabetes: compliance with good practice. Nurse Prescribing. 2009;7(10):464-8.

67. BMA. British National Formulary. London: BMA, \& Royal Pharmaceutica Society; 2015.

68. Courtenay M, Carey N, Stenner K. Nurse prescriber-patient consultations: a case study in dermatology. J Adv Nurs. 2009;65(6):1207-17.

69. NHS Careers. Agenda for change-pay rates. https://www.healthcareers.nhs. uk/working-health/working-nhs/nhs-pay-and-benefits/agenda-change-payrates2020. Accessed 5 Jan 2020.

70. Courtenay M, Carey N, Stenner K, Gage H, Williams P. A comparison of prescribing and non-prescribing nurses in the management of people with diabetes. J Adv Nurs. 2015;71(12):2950-64.

71. Baker R. Development of a questionnaire to assess patients' satisfaction with consultations in general practice. Br J Gen Pract. 1990;40:487-90.

72. Baker $R$, Whitfield M. Measuring patient satisfaction: a test of construct validity. Q Healthcare. 1992;1:104-9.

73. Curtis L, Burns A. Unit costs of health and social care. Personal and Social Services Research Unit: http://www.pssru.ac.uk/index-kent-Ise.php2016. Accessed 18 Apr 2016

74. Devlin N, Shah K, Feng Y, Mulhern B, van Hout B. Valuing Health-Related Quality of Life: An EQ-5D-5L Value Set for England: Research Paper 16/01. London: Office of Health Economics Research; 2016.

75. DH. Extending the practice of allied health professionals in the NHS. Briefing paper. London: NHS Service Delivery and Organisation: Research and Development; 2006.

76. DH. Equity and excellence:l Liberating the NHS. London: DH; 2010.
77. NHS. The NHS Long Term Plan. 2019: https://www.longtermplan.nhs.uk/wpcontent/uploads/2019/08/nhs-long-term-plan-version-1.2.pdf accessed 27th August 2019.

78. Schäfer WLA, WGW B, Murante AM, HJM S, Schellevisa FG, Groenewegen PP. Assessing the potential for improvement of primary care in 34countries: a cross-sectional survey. Bull World Health Organisation. 2015;15(93):161-8. https://doi.org/10.2471/BLT.14.140368.

79. NHS Digital. Practice Level Prescribing June 2019. 2019. https://digital.nhs. uk/data-and-information/publications/statistical/practice-level-prescribingdata/june-2019 accessed August 15th 2019.

80. Stokes-Lampard H. Primary care: workforce pressures. London: The Nuffield Trust; 2017.

81. Kaffash J. GPs vote for home visits to be removed from contract. Pulse. 2019; http://www.pulsetoday.co.uk/news/gps-vote-for-home-visits-to-beremoved-from-contract/20039743. article:accessed Nov 26th 2019.

82. Kaffash J. Conservatives pledge 6,000 new doctors in general practice by 2024/25. Pulse. 2019; http://www.pulsetoday.co.uk/news/conservativespledge-6000-new-doctors-in-general-practice-by-2024/25/20039665.article: accessed 19th November 2019.

83. DH. The NHS Long Term Plan. London: Department of Health; 2019

84. NHS England, Care Quality Commission, Health Education England M, NHS Trust Development Authority, England PH. Five year forward view. 2014 (accessed 24th November 2016) available from www.england.nhs.uk/ ourwork/futurenhs/nhs-five-year-forwardview.

85. DH and Department for Communities and Local Government. Better Care Fund: Policy Framework: DH, 2014.

86. DH. The Musculoskeletal framework: Report: 270211. London: Department of Health; 2006

87. Gilburt H. Supporting integration through new roles and working across boundaries. The Kings Fund; 2016.

88. Chartered Society of Physiotherapy. Physios key in MD teams developing new ways of working: 2009 (accessed November 24th 2016) available from http://www.csp.org.uk/frontline/article/physios-key-md-teams-developingnew-ways-working:

89. Nelson PMA-M, McBride A, Checkland K, Hodgson D. Skill-mix change and the general practice workforce challenge. Br J Gen Pract. 2018;68(667):66-7. https://doi.org/10.3399/bjgp18X694469 accessed 27th August 2019.

\section{Publisher's Note}

Springer Nature remains neutral with regard to jurisdictional claims in published maps and institutional affiliations.

Ready to submit your research? Choose BMC and benefit from:

- fast, convenient online submission

- thorough peer review by experienced researchers in your field

- rapid publication on acceptance

- support for research data, including large and complex data types

- gold Open Access which fosters wider collaboration and increased citations

- maximum visibility for your research: over $100 \mathrm{M}$ website views per year

At $\mathrm{BMC}$, research is always in progress.

Learn more biomedcentral.com/submissions 